\title{
Protic ionic liquids with low viscosity for efficient and reversible capture of carbon
} dioxide

\author{
Li, Fangfang; Bai, Yinge; Zeng, Shaojuan; Liang, Xiaodong; Wang, Hui; Huo, Feng; Zhang, Xiangping
}

Published in:

International Journal of Greenhouse Gas Control

Link to article, DOI:

10.1016/j.ijggc.2019.102801

Publication date:

2019

Document Version

Peer reviewed version

Link back to DTU Orbit

Citation $(A P A)$ :

Li, F., Bai, Y., Zeng, S., Liang, X., Wang, H., Huo, F., \& Zhang, X. (2019). Protic ionic liquids with low viscosity for efficient and reversible capture of carbon dioxide. International Journal of Greenhouse Gas Control, 90, [102801]. https://doi.org/10.1016/j.ijggc.2019.102801

\section{General rights}

Copyright and moral rights for the publications made accessible in the public portal are retained by the authors and/or other copyright owners and it is a condition of accessing publications that users recognise and abide by the legal requirements associated with these rights.

- Users may download and print one copy of any publication from the public portal for the purpose of private study or research.

- You may not further distribute the material or use it for any profit-making activity or commercial gain

- You may freely distribute the URL identifying the publication in the public portal 


\section{Protic ionic liquids with low viscosity for efficient and reversible capture of carbon dioxide}

Fangfang Li ${ }^{\mathrm{a}, \mathrm{b}}$, Yinge Bai ${ }^{\mathrm{a}}$, Shaojuan Zeng ${ }^{\mathrm{a},{ }^{* *}}$, Xiaodong Liang ${ }^{\mathrm{c}}$, Hui Wang ${ }^{\mathrm{a}}$, Feng Huo ${ }^{\mathrm{a}}$, Xiangping Zhanga,b,*

a Beijing Key Laboratory of Ionic Liquids Clean Process, CAS Key Laboratory of Green Process and Engineering, State Key Laboratory of Multiphase Complex Systems, Institute of Process Engineering, Chinese Academy of Sciences, Beijing 100190, China

b Sino-Danish College of University of Chinese Academy of Sciences, Beijing 100049, China

c Department of Chemical and Biochemical Engineering, Technical University of Denmark, DK-2800 Lyngby, Denmark

${ }^{*}$ Corresponding author. E-mail: xpzhang@ipe.ac.cn, Tel/Fex: 86-10-8254-4875

** Corresponding author. E-mail: sjzeng@ipe.ac.cn 


\section{Abstract}

Protic ionic liquids (PILs) are considered as potential solvents for $\mathrm{CO}_{2}$ capture due to their simple synthetic routes and unique properties. In this work, three low viscous PILs, tetramethylgunidinium imidazole ([TMGH][Im]), tetramethylgunidinium pyrrole ([TMGH][Pyrr]) and tetramethylgunidinium phenol ([TMGH][PhO]) were synthesized and the effect of anions, temperature, $\mathrm{CO}_{2}$ partial pressure and water content on $\mathrm{CO}_{2}$ absorption performance of PILs was also systematically studied. It was found that the PILs with larger basicity show higher $\mathrm{CO}_{2}$ absorption capacity, and [TMGH][Im] simultaneously shows relatively high absorption rate and $\mathrm{CO}_{2}$ absorption capacity of $0.154 \mathrm{~g} \mathrm{CO}_{2} / \mathrm{g}$ IL at $40{ }^{\circ} \mathrm{C}, 1 \mathrm{bar}$. The addition of $\mathrm{H}_{2} \mathrm{O}$ has a positive effect on gravimetric absorption capacity of $\mathrm{CO}_{2}$ at the range of $0-20 \mathrm{wt} \% \mathrm{H}_{2} \mathrm{O}$, and the highest capacity of $0.186 \mathrm{~g} \mathrm{CO}_{2} / \mathrm{g}$ IL was achieved as the water content was $7 \mathrm{wt} \%$. In-situ FTIR, ${ }^{13} \mathrm{C}$ NMR and theoretical calculations verified that more stable bicarbonate are produced during $\mathrm{CO}_{2}$ absorption by $[\mathrm{TMGH}][\mathrm{Im}]-\mathrm{H}_{2} \mathrm{O}$ system. However, neat $[\mathrm{TMGH}][\mathrm{Im}]$ can react with $\mathrm{CO}_{2}$ to form the reversible carbamate, leading to excellent recyclability after four absorption-desorption cycles. The results implied that neat [TMGH][Im] shows great potentials in $\mathrm{CO}_{2}$ absorption applications.

Keywords: Ionic liquids, protic, low viscosity, $\mathrm{CO}_{2}$ absorption, mechanisms 


\section{Introduction}

Greenhouse effect caused by carbon dioxide $\left(\mathrm{CO}_{2}\right)$ emission has become one of the most serious environmental problems in the global area and awakened wide attention due to the excessive combustion of fossil fuels (Mondal et al., 2012). Therefore, developing new technologies to reduce $\mathrm{CO}_{2}$ emission is the main concern (Guo et al., 2015; Ozturk, 2015; Lazarevic et al., 2017). One of the most promising methods to mitigate the impact of greenhouse gas for climate change and $\mathrm{CO}_{2}$ utilization is developing carbon dioxide capture and storage technologies (CCS) (Deng, 2016). Alkanolamines (including monoethanolamine, diethanolamine and $\mathrm{N}$ methyldiethanolamine) are the most commonly applied solvents for $\mathrm{CO}_{2}$ capture in industries (Han et al., 2011). However, aqueous alkanolamines for $\mathrm{CO}_{2}$ capture have some intrinsic drawbacks, such as corrosivity and degradation during the regeneration of solvents. Besides, large heat capacity of water and easy volatilization of alkanolamines result in high solvent loss and intensive energy consumption (Vaidya and Kenig, 2007). Accordingly, there is a pressing demand for seeking novel $\mathrm{CO}_{2}$ capture solvents with favorable absorption performance, low solvent loss and energy consumption.

Ionic liquids (ILs) have emerged as potential solvents for gas separation (Zhang et al., 2013; Gao et al., 2015; Cao et al., 2017; Shang et al., 2017; Zhu et al., 2017) due to their outstanding properties, such as high thermal stability, low heat capacity, negligible vapor pressure and adjustable nature. ILs as $\mathrm{CO}_{2}$ absorbents is one of the most effective alternatives to replace conventional aqueous alkanolamines solvents. Since Blanchard 
et al. (1999) reported that $\mathrm{CO}_{2}$ can dissolve in ILs, while ILs do not dissolve in $\mathrm{CO}_{2}$, a large number of publications on $\mathrm{CO}_{2}$ capture by ILs through physical interaction were reported (Palomar et al., 2011; Sistla and Khanna, 2011; Zhao et al., 2011; Ramdin et al., 2012). However, $\mathrm{CO}_{2}$ absorption capacity in these ILs is only about $0.03 \mathrm{~mol}$ $\mathrm{CO}_{2} /$ mol IL under atmospheric pressure (Wang et al., 2011). In order to improve $\mathrm{CO}_{2}$ absorption capacity in ILs, the chemisorption ILs were designed by introducing basic functional groups into ILs. Bates et al. (2002) proposed a new strategy for chemical absorption of $\mathrm{CO}_{2}$ by amino-functionalized IL 1-propylamide-3-butylimidazolium tetrafluoroborate ([apbim] $\left[\mathrm{BF}_{4}\right]$ ), the absorption capacity of $\mathrm{CO}_{2}$ in this IL is $0.074 \mathrm{~g}$ $\mathrm{CO}_{2} / \mathrm{g}$ IL at room temperature and atmospheric pressure. Subsequently, there have been many reports on $\mathrm{CO}_{2}$ absorption using amino-functionalized ILs, including aminebased and amino acid-based ILs (Hu et al., 2014; Lv et al., 2016; Huang et al., 2018). Riisager et al (2014). synthesized a series of amino acid-based ILs as $\mathrm{CO}_{2}$ absorbents, and high $\mathrm{CO}_{2}$ capacity of $0.13 \mathrm{~g} \mathrm{CO}_{2} / \mathrm{g}$ IL was measured for $\left[\mathrm{N}_{66614}\right][\mathrm{Lys}]$ at ambient condition. Recently, an extremely high $\mathrm{CO}_{2}$ capacity up to $0.25 \mathrm{~g} \mathrm{CO}_{2} / \mathrm{g}$ IL have been achieved by using tri- $n$-butylethylphosphonium succinimide $\left(\left[\mathrm{P}_{4442}\right][\mathrm{Suc}]\right)$ (Huang et al., 2017). Nevertheless, the difficulty in chemisorbing ILs is the extremely high viscosity and complex synthetic routes of most task-specific ILs. For example, $\left[\mathrm{P}_{4442}\right][\mathrm{Suc}]$ with a viscosity as high as $998 \mathrm{mPa} \cdot \mathrm{s}$ at $20^{\circ} \mathrm{C}$ should be prepared through anion-exchange and neutralization reaction. Consequently, developing novel taskspecific ILs with high $\mathrm{CO}_{2}$ absorption performance, simple synthetic routes and low viscosity are the main tasks for $\mathrm{CO}_{2}$ capture. 
Protic ionic liquids (PILs) can be easily obtained through a neutralization reaction of Brønsted acid and base. Recently, PILs have caught considerable attention in $\mathrm{CO}_{2}$ capture fields due to their simpler synthetic routes and lower costs compared to most of aprotic ionic liquids (AILs) (Mumford et al., 2015; Xu, 2017; Oncsik et al., 2018). For example, Alcantara et al. (2018) studied the $\mathrm{CO}_{2}$ absorption performance in four potential PILs which were synthetized through one-step neutralization of diethylamine/ethanolamines and butanoic acids. The results indicated that the PILs 2hydroxyethylammonium butanoate ([2HEA][Bu]) and N-methyl-2hydroxyethylammonium butanoate $([\mathrm{m}-2 \mathrm{HEA}][\mathrm{Bu}])$ exhibited significant higher $\mathrm{CO}_{2}$ solubility than most ILs ones analyzed. Tetramethylguanidine (TMG), as a common kind of superbase, has been widely reacted with proton donors and the obtained TMGbased PILs were frequently used in different fields (Reddy et al., 2015; Porwal et al., 2016; Singh et al., 2017). In recent years, TMG-based PILs were applied in acid gases absorption due to low viscosity, simple synthetic routes and excellent absorption performance (Jin et al., 2011; Meng et al., 2018). However, current research of TMGbased PILs mainly focused on sulfur dioxide $\left(\mathrm{SO}_{2}\right)$ absorption, rarely on $\mathrm{CO}_{2}$ absorption. The efficiency of $\mathrm{SO}_{2}$ absorption mainly related to the reaction of $\mathrm{SO}_{2}$ with $\mathrm{N}-\mathrm{H}$ group in $[\mathrm{TMGH}]^{+}$cation forming an N-S bond (Wu et al., 2004), while the reactivity of $\mathrm{CO}_{2}$ and $[\mathrm{TMGH}]^{+}$cation is not valid because of the low acidity of $\mathrm{CO}_{2}$ (Jessop et al., 2012). Recently, a novel method for $\mathrm{CO}_{2}$ capture by tunable anionfunctionalized PILs based on the single-site interaction between the $\mathrm{CO}_{2}$ and electronegative nitrogen or oxygen atom was reported, it was shown that $\mathrm{CO}_{2}$ 
absorption capacity can be easily tuned by the IL basicity (Wang et al., 2011). Therefore, anion-functionalized PILs with TMG as the proton acceptor combining with reactive hydrogen in azole or phenol is suitable for $\mathrm{CO}_{2}$ absorption because of the strong basicity of TMG.

In this work, considering the significant role of IL basicity on $\mathrm{CO}_{2}$ absorption (Wang et al., 2011), three basic PILs were designed and synthesized by neutralizing TMG with different weak proton donors, including imidazole (Im), pyrrole (Pyrr) and phenol $(\mathrm{PhO})$ with different dissociation constant $\left(\mathrm{p} K_{\mathrm{a}}\right) \cdot \mathrm{CO}_{2}$ absorption performance of these ILs, including the effect of anions, temperature, $\mathrm{CO}_{2}$ partial pressure and water content on $\mathrm{CO}_{2}$ absorption, as well as recyclability in the absence and presence of $\mathrm{H}_{2} \mathrm{O}$ were systematically studied. The $\mathrm{CO}_{2}$ absorption mechanisms of these systems were also investigated by in-situ FTIR, ${ }^{13} \mathrm{C}$ NMR analysis and theoretical calculations.

\section{Experimental section}

\subsection{Materials}

The materials TMG, Im and Pyrr were purchased from Aladdin Industrial Corporation. PhO was obtained from Xilong Scientific Limited. All the above chemical reagents were obtained in the analytical purity grade and used without further purification. $\mathrm{CO}_{2}\left(>99.9 \%\right.$ purity) and nitrogen $\left(\mathrm{N}_{2},>99.9 \%\right.$ purity) gases were supplied by Beijing Beiwen Gases Factory.

\subsection{Synthesis and characterization of PILs}

Three target basic PILs, tetramethylgunidinium imidazole [TMGH][Im], 
tetramethylgunidinium pyrrole $[\mathrm{TMGH}][\mathrm{Pyrr}]$ and tetramethylgunidinium phenol $[\mathrm{TMGH}][\mathrm{PhO}]$ were prepared by direct neutralization of an appropriate TMG with different weak proton donors ( $\mathrm{Im}, \mathrm{Pyrr}$ and $\mathrm{PhO}$ ) at room temperature and atmospheric pressure for $24 \mathrm{~h}$ (Scheme 1), and the synthetic procedures were similar to our previous work (Zhao et al., 2010, 2011). After that, all the ILs were dried in the vacuum oven at $60{ }^{\circ} \mathrm{C}$ for $40 \mathrm{~h}$ before use. The water contents in these ILs were measured by using Karl Fischer titration (Mettler Toledo Coulometric KF titrator $\mathrm{C} 20$ ), and all the water contents were below 320 ppm.

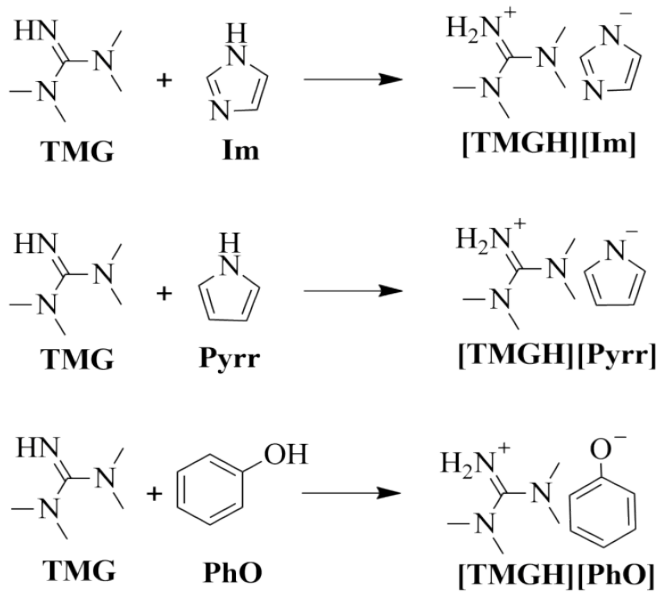

Scheme 1. Synthesis of [TMGH][Im], [TMGH][Pyrr] and [TMGH][PhO].

The obtained samples were characterized by ${ }^{1} \mathrm{H}$ and ${ }^{13} \mathrm{C}$ NMR using Bruker 600 spectormeter. FTIR spectra of these ILs were recorded in the range of $3600-400 \mathrm{~cm}^{-1}$ using Thermo Nicolet 380 spectrometer. Density and viscosity were measured using density meter (Anton Paar DMA 5000) and viscometer (Anton Paar AMVn) from 30 to $80{ }^{\circ} \mathrm{C}$ with $10{ }^{\circ} \mathrm{C}$ intervals under atmospheric pressure. The thermal stability of these ILs was measured using TGA Q5000 V3.15 with a heat rate of $10{ }^{\circ} \mathrm{C} / \mathrm{min}$ in $\mathrm{N}_{2}$ atmosphere at a flow rate of $20 \mathrm{ml} / \mathrm{min}$. The ${ }^{1} \mathrm{H}$ NMR, ${ }^{13} \mathrm{C}$ NMR, FTIR spectra and 
TGA data of all the studied PILs were concluded in the Supporting Information.

\subsection{Absorption and desorption of $\mathrm{CO}_{2}$}

The experimental setup for $\mathrm{CO}_{2}$ absorption is schematically represented in Scheme 2, and followed the procedures according to our previous work (Wang et al., 2014; Zeng et al., 2014, 2018). The absorption experiments were carried out in a glass container with an inner diameter of $2 \mathrm{~cm}$. In a typical experiment, $\mathrm{CO}_{2}$ gas (1) was bubbled through IL (about $5 \mathrm{~g}$ ) in the glass container (9) at a flow rate of about 140 $\mathrm{ml} / \mathrm{min}$. The glass container was partly immersed in the water bath (8) at the desired temperature (the standard uncertainty of temperature is $\pm 0.1^{\circ} \mathrm{C}$ ). The amount of absorbed $\mathrm{CO}_{2}$ was determined at regular intervals by an electronic balance with an accuracy of $\pm 0.1 \mathrm{mg}$, which could remain constant when absorption of $\mathrm{CO}_{2}$ reached to equilibrium. To ensure precision during weight measurements of samples, the glass container was dried outside before weighted.

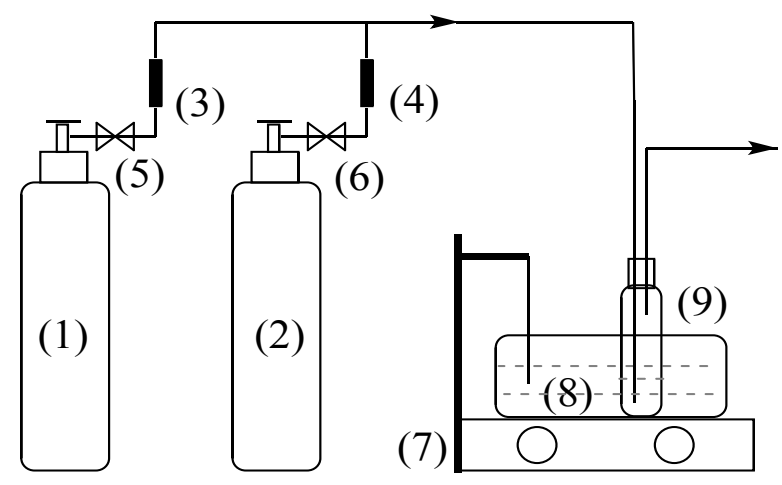

Scheme 2. Experimental diagram for $\mathrm{CO}_{2}$ absorption. (1) $\mathrm{CO}_{2}$ gas cylinder; (2) $\mathrm{N}_{2}$ gas cylinder; (3) and (4) gas mass flowmeter; (5) and (6) valves; (7) magnetic stirrer; (8) water bath; (9) glass container with IL. 
The effect of temperature on $\mathrm{CO}_{2}$ absorption performance of ILs was carried out under atmospheric pressure by varying temperatures from 30 to $50{ }^{\circ} \mathrm{C}$. During $\mathrm{CO}_{2}$ absorption under reduced pressure, the absorption temperature was kept constant at $40{ }^{\circ} \mathrm{C}$, the mixed gases with different $\mathrm{CO}_{2}$ partial pressure were prepared by adjusting the flow rate of $\mathrm{CO}_{2}$ and $\mathrm{N}_{2}$ gases. To investigate the influence of water content on $\mathrm{CO}_{2}$ absorption, $\mathrm{CO}_{2}$ saturated with water vapor was bubbled through IL in the presence of different water content with $140 \mathrm{ml} / \mathrm{min}$ flow rate at $40{ }^{\circ} \mathrm{C}$ and atmospheric pressure.

For desorption process, $\mathrm{CO}_{2}$-absorbed IL was transferred to a round-bottom flask and $\mathrm{CO}_{2}$ was released by rotary evaporation at $60{ }^{\circ} \mathrm{C}$ for $2 \mathrm{~h}$. The desorption of $\mathrm{CO}_{2}$ from IL- $\mathrm{H}_{2} \mathrm{O}$ system was similar to neat IL system, rotary evaporator was used to remove most of $\mathrm{CO}_{2}$ and $\mathrm{H}_{2} \mathrm{O}$ in $\mathrm{CO}_{2}$ absorbed $\mathrm{IL}-\mathrm{H}_{2} \mathrm{O}$ system, the obtained product was dried in vacuum oven for $24 \mathrm{~h}$ to remove the residual moisture. Then fresh water was added to the obtained product at a certain ratio for next $\mathrm{CO}_{2}$ absorption.

\subsection{Computational methods}

All calculations herein were performed with the Gaussian 09 program (Frisch et al., 2013) by using Density Functional Theory. All geometries of reactants, transition states and products were optimized at the M06-2X/def2-TZVP level of theory. The solvent effects of ILs were simulated by the SMD-GIL solvation model (Bernales et al., 2012). The frequency calculation was carried out at the same level to confirm the optimized structures to be energy minima without any imaginary frequency, and transition states has one and only one imaginary frequency. The interaction energies (or 
energy barriers) were calculated as the energy difference between the products (or transition states) and the reactants.

\section{Results and discussion}

\subsection{Physical properties of PILs}

Physical properties, such as density and viscosity of ILs are important parameters for industrial application of $\mathrm{CO}_{2}$ absorbents. Therefore, densities and viscosities of these PILs at various temperatures were measured and the results are shown in Fig. 1 and 2, respectively. The experimental density results for three ILs from 30 to $80{ }^{\circ} \mathrm{C}$ showed that temperature dependences of ILs densities have the linear behavior and decreased with the increasing of temperature. The density order of these ILs are: $[\mathrm{TMGH}][\mathrm{PhO}]>[\mathrm{TMGH}][\mathrm{Im}]>[\mathrm{TMGH}][\mathrm{Pyrr}]$.

The viscosity of absorbents has significant effect on mass transfer during $\mathrm{CO}_{2}$ absorption. ILs with low viscosities can result in low mass transfer resistance between liquid and gas phases, and thereby increase $\mathrm{CO}_{2}$ absorption rate. As seen in Fig. 2, the viscosities of all studied ILs decreased with an increase in temperature. The viscosities of [TMGH][Im], [TMGH][Pyrr] and [TMGH][PhO] were 6.44, 2.10 and $26.77 \mathrm{mPa} \cdot \mathrm{s}$ at $30^{\circ} \mathrm{C}$, respectively, which are far lower than most of conventional ILs, for example, the viscosity of $[\mathrm{Bmim}]\left[\mathrm{BF}_{4}\right]$ was $68.90 \mathrm{mPa} \cdot \mathrm{s}$ at $30{ }^{\circ} \mathrm{C}$ (Zhao et al., 2010). The results indicated that all these ILs have relatively low viscosities, which facilitate $\mathrm{CO}_{2}$ diffusion in ILs during absorption processes. 


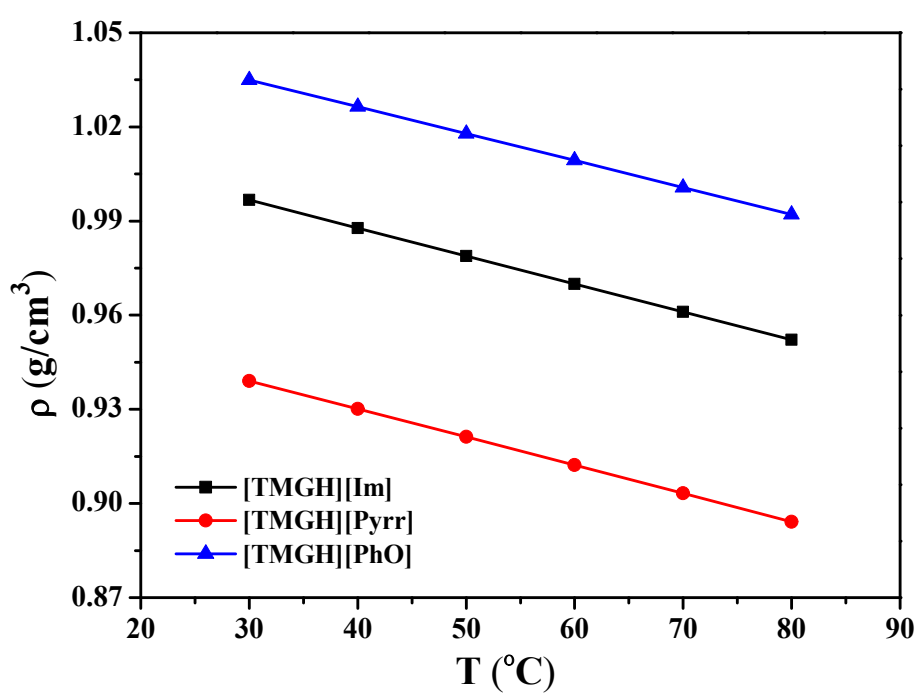

Fig. 1. Densities of [TMGH][Im], [TMGH] $[\mathrm{Pyrr}]$ and $[\mathrm{TMGH}][\mathrm{PhO}]$ at various temperatures.

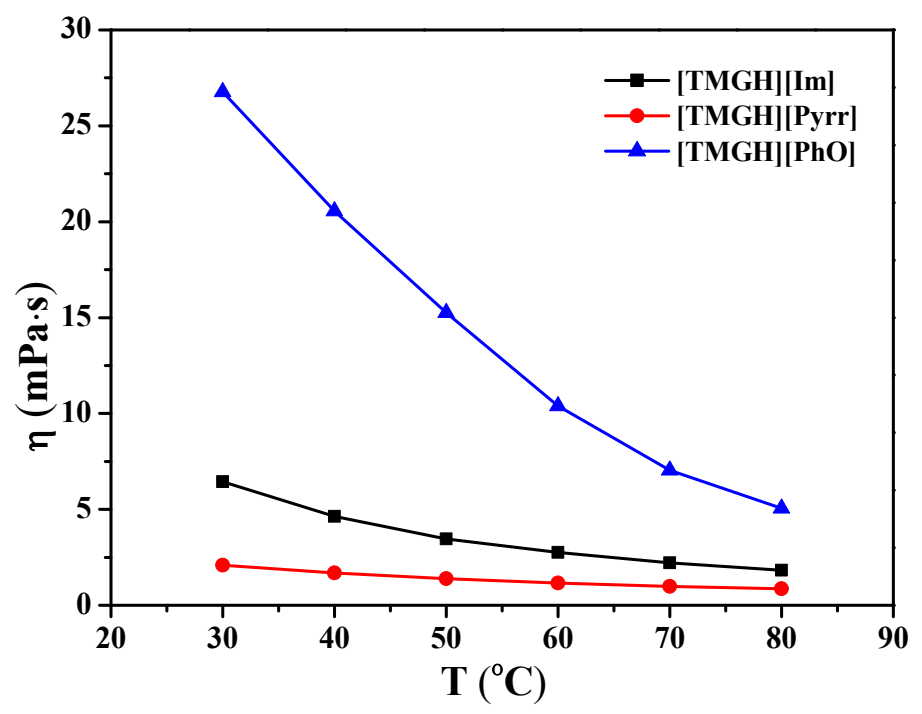

Fig. 2. Viscosities of [TMGH][Im], [TMGH] $[\mathrm{Pyrr}]$ and $[\mathrm{TMGH}][\mathrm{PhO}]$ at various temperatures.

\subsection{Effect of anions on $\mathrm{CO}_{2}$ absorption}

In order to investigate the $\mathrm{CO}_{2}$ absorption performance in these PILs, $\mathrm{CO}_{2}$ capture experiments were firstly carried out in three PILs with different anions, [TMGH][Im], $[\mathrm{TMGH}][\mathrm{Pyrr}]$ and $[\mathrm{TMGH}][\mathrm{PhO}]$ at $40{ }^{\circ} \mathrm{C}$ under atmospheric pressure in Fig. 3. It was 
found that $\mathrm{CO}_{2}$ absorption in all the ILs is very quick at the beginning, then decreased gradually and finally achieved equilibrium. Among the three ILs, [TMGH][Im] and [TMGH][Pyrr] exhibited higher $\mathrm{CO}_{2}$ absorption capacity of 0.154 and $0.159 \mathrm{~g} \mathrm{CO}_{2} / \mathrm{g}$ IL, respectively, while $\mathrm{CO}_{2}$ absorption capacity of [TMGH][PhO] was only $0.010 \mathrm{~g}$ $\mathrm{CO}_{2} / \mathrm{g}$ IL at the same condition. In fact, $\mathrm{CO}_{2}$ absorption capacity is significantly affected by the basicity of ILs. In general, the anion of ILs with larger $\mathrm{pKa}$ has higher $\mathrm{CO}_{2}$ absorption capacity due to its stronger reactivity with $\mathrm{CO}_{2}$ (Wang et al., 2011). As shown in Table 1, when the $\mathrm{pKa}$ of anions in DMSO decreased from 23.0 to $16.4, \mathrm{CO}_{2}$ molar absorption capacity decreased remarkably from 0.66 to $0.05 \mathrm{~mol} \mathrm{CO} / \mathrm{mol} \mathrm{IL}$.

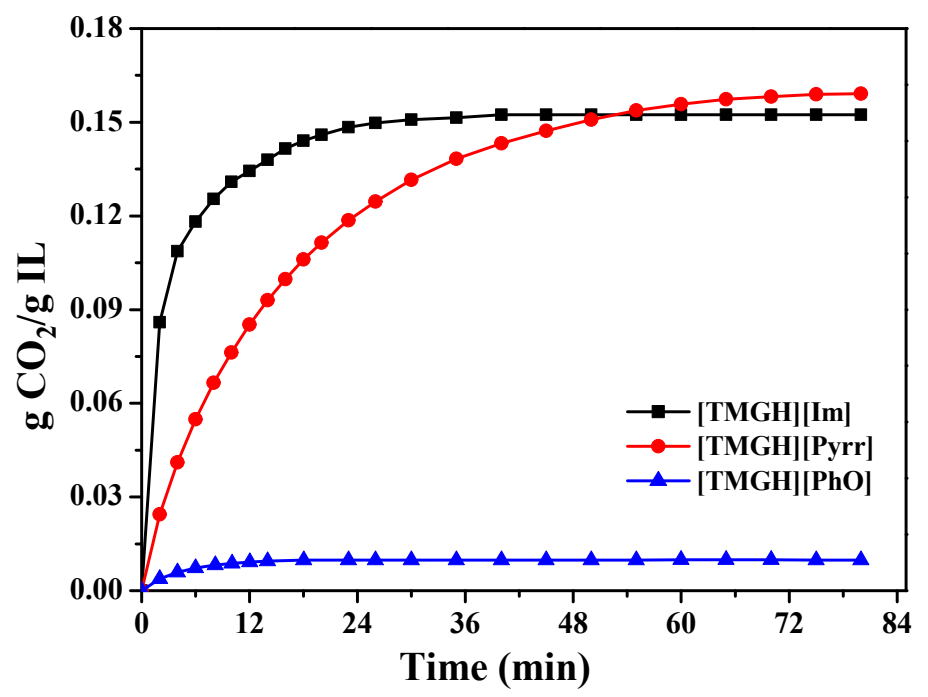

Fig. 3. $\mathrm{CO}_{2}$ absorption in $[\mathrm{TMGH}][\mathrm{Im}]$, $[\mathrm{TMGH}][\mathrm{Pyrr}]$ and $[\mathrm{TMGH}][\mathrm{PhO}]$ at $40{ }^{\circ} \mathrm{C}$ and 1 bar. 
Table 1: The effect of anions $\mathrm{p} K_{\mathrm{a}}$ on the $\mathrm{CO}_{2}$ absorption capacity.

\begin{tabular}{ccccc}
\hline IL & $\mathrm{M}(\mathrm{g} / \mathrm{mol})$ & $\mathrm{T}\left({ }^{\circ} \mathrm{C}\right)$ & $\begin{array}{c}\text { Capacity } \\
\left(\mathrm{mol} \mathrm{CO}_{2} / \mathrm{mol} \mathrm{IL}\right)\end{array}$ & $\mathrm{p} K_{\mathrm{a}}$ in DMSO \\
\hline$[\mathrm{TMGH}][\mathrm{Pyrr}]$ & 182.27 & 40 & 0.66 & $\begin{array}{c}23.0 \text { (Bordwell } \\
\text { et al., 1981) }\end{array}$ \\
{$[\mathrm{TMGH}][\mathrm{Im}]$} & 183.26 & 40 & 0.64 & $\begin{array}{c}18.6 \\
\text { (Bordwell, } \\
1988)\end{array}$ \\
{$[\mathrm{TMGH}][\mathrm{PhO}]$} & 209.29 & 40 & 0.05 & $\begin{array}{c}16.4 \text { (Ritchie, } \\
1969)\end{array}$ \\
\hline
\end{tabular}

Meanwhile, $[\mathrm{TMGH}][\mathrm{Im}]$ also showed the faster rate of $\mathrm{CO}_{2}$ absorption than other PILs, and the absorption can achieve equilibrium in $20 \mathrm{~min}$. Although [TMGH][Pyrr] has the lowest viscosity, the absorption of $\mathrm{CO}_{2}$ was completed in nearly $60 \mathrm{~min}$, which is substantially three times that of $[\mathrm{TMGH}][\mathrm{Im}]$. The possible reason is that the solid state product was observed in [TMGH] [Pyrr] after $\mathrm{CO}_{2}$ absorption, which caused an increase in the apparent slurry viscosity, and reduction in effective diffusivity of $\mathrm{CO}_{2}$ in the liquid (Kumar et al., 2003). As described above, [TMGH][Im] has a relative high $\mathrm{CO}_{2}$ absorption capacity and the highest absorption rate compared with the other two ILs, which can be considered as a candidate solvent for $\mathrm{CO}_{2}$ capture. Therefore, the effect of temperature, $\mathrm{CO}_{2}$ partial pressure and water content on $\mathrm{CO}_{2}$ absorption performance in [TMGH][Im] were further investigated and discussed.

\subsection{Effect of temperature on $\mathrm{CO}_{2}$ absorption}

Temperature plays a key role in $\mathrm{CO}_{2}$ absorption process, hence the effect of 
temperature on $\mathrm{CO}_{2}$ absorption performance of [TMGH][Im] was investigated from 30 to $50{ }^{\circ} \mathrm{C}$ under atmospheric pressure as shown in Fig. 4. The results indicated that $\mathrm{CO}_{2}$ absorption capacity decreased obviously with temperature increasing. The absorption capacity of $[\mathrm{TMGH}][\mathrm{Im}]$ was $0.177 \mathrm{~g} \mathrm{CO}_{2} / \mathrm{g} \mathrm{IL}$ at $30^{\circ} \mathrm{C}$, but reduced to $0.124 \mathrm{~g} \mathrm{CO}_{2} / \mathrm{g}$ $\mathrm{IL}$ at $50{ }^{\circ} \mathrm{C}$. This is because $\mathrm{CO}_{2}$ absorption is an exothermic process, and the increasing of temperature is not favorable for $\mathrm{CO}_{2}$ absorption. On the other hand, increasing temperature has a positive influence on mass transfer during the absorption of $\mathrm{CO}_{2}$ due to lower viscosity of absorbents at higher temperature, and finally decreases saturation time. The saturation time decreased from 40 to $15 \mathrm{~min}$ when temperature changed from 30 to $50{ }^{\circ} \mathrm{C}$.

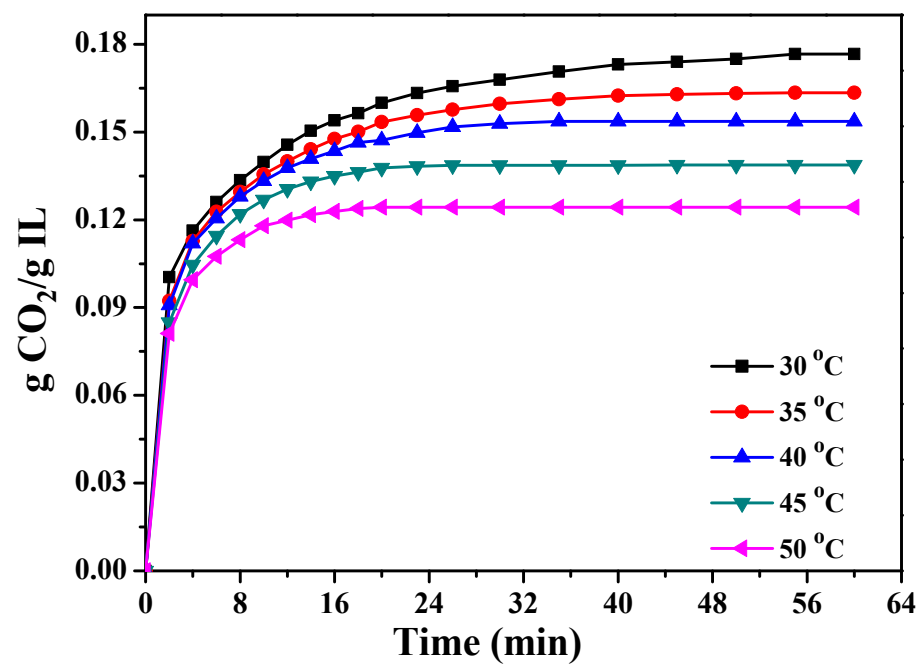

Fig. 4. $\mathrm{CO}_{2}$ absorption in $[\mathrm{TMGH}][\mathrm{Im}]$ at various temperatures.

\subsection{Effect of partial pressure on $\mathrm{CO}_{2}$ absorption}

In industrial processes, $\mathrm{CO}_{2}$ frequently coexists with other gases and $\mathrm{CO}_{2}$ partial pressure almost lower than 1.0 bar. As illustrated in Fig. 5, $\mathrm{CO}_{2}$ absorption performance of $[\mathrm{TMGH}][\mathrm{Im}]$ was carried out at $40{ }^{\circ} \mathrm{C}$ with a $\mathrm{CO}_{2}$ partial pressure of $0.1,0.3,0.5$, 
0.7, 0.9 and 1.0 bar to study the effect of $\mathrm{CO}_{2}$ partial pressure on $\mathrm{CO}_{2}$ absorption. With the decreasing of $\mathrm{CO}_{2}$ partial pressure, $\mathrm{CO}_{2}$ absorption capacity of [TMGH][Im] reduced gradually. The absorption capacity of [TMGH][Im] was as low as $0.05 \mathrm{~g} \mathrm{CO}_{2} / \mathrm{g}$ IL at 0.1 bar. From the investigation of the effect of temperature and $\mathrm{CO}_{2}$ partial pressure on $\mathrm{CO}_{2}$ absorption performance, both increasing $\mathrm{CO}_{2}$ partial pressure and reducing temperature are benefit for enhancing $\mathrm{CO}_{2}$ absorption capacity.

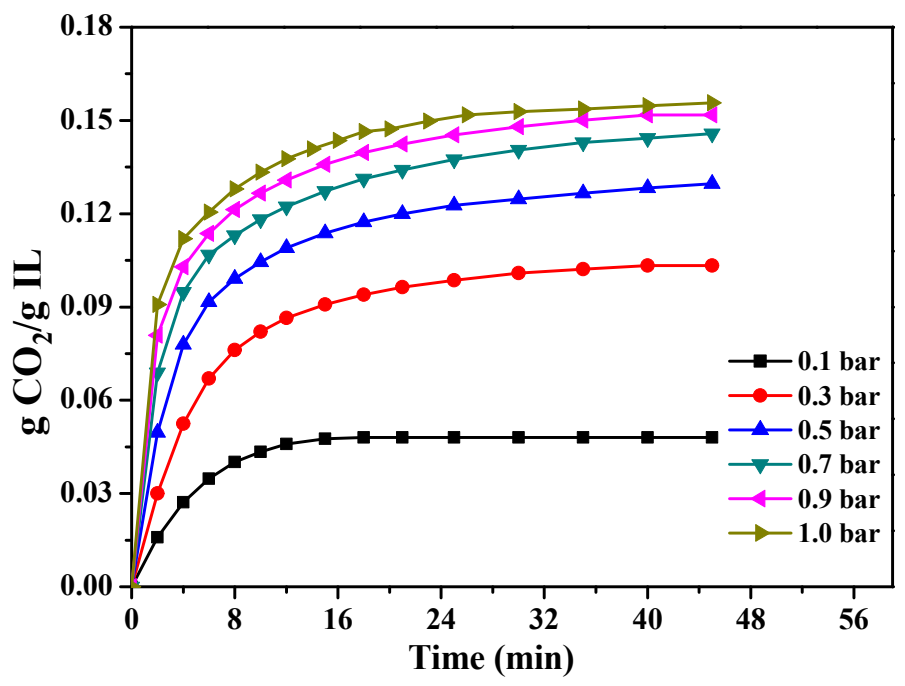

Fig. 5. $\mathrm{CO}_{2}$ absorption in $[\mathrm{TMGH}][\mathrm{Im}]$ at various $\mathrm{CO}_{2}$ partial pressures.

\subsection{Effect of water content on $\mathrm{CO}_{2}$ absorption}

The effect of water content on $\mathrm{CO}_{2}$ absorption performance of [TMGH][Im] was also investigated under $40{ }^{\circ} \mathrm{C}$ and atmospheric pressure. As seen in Fig. 6 and 7, water contents can remarkably affect the $\mathrm{CO}_{2}$ capacity of [TMGH][Im] At the beginning, both $\mathrm{CO}_{2}$ gravimetric and molar absorption capacity increased greatly with the increasing of water content, the highest absorption capacity up to $0.186 \mathrm{~g} \mathrm{CO}_{2} / \mathrm{g}$ absorbent $(0.83 \mathrm{~mol} \mathrm{CO} / \mathrm{mol} \mathrm{IL})$ when $7 \mathrm{wt} \% \mathrm{H}_{2} \mathrm{O}$ was added to [TMGH][Im]. $\mathrm{CO}_{2}$ gravimetric absorption capacity of absorbents reduced with an increase of water content 
but still higher than that in neat $[\mathrm{TMGH}][\mathrm{Im}]$ in the range from 7 to $20 \mathrm{wt} \% \mathrm{H}_{2} \mathrm{O}$, which was $0.161 \mathrm{~g} \mathrm{CO}_{2} / \mathrm{g}$ absorbent in $80 \mathrm{wt} \%$ [TMGH][Im]-20 wt $\% \mathrm{H}_{2} \mathrm{O}$ system, but $\mathrm{CO}_{2}$ molar absorption capacity was almost maintain at $0.83 \mathrm{~mol} \mathrm{CO}_{2} / \mathrm{mol} \mathrm{IL}$. The possible reason is that $\mathrm{CO}_{2}$ can directly react with the imidazole anion to form the carbamate product in neat $[\mathrm{TMGH}][\mathrm{Im}]$, while in the presence of $\mathrm{H}_{2} \mathrm{O}$, the imidazole anion interacts more strongly with the $\mathrm{H}_{2} \mathrm{O}$ than $\mathrm{CO}_{2}$, and a more stable bicarbonate and neutral Im may generate after absorption of $\mathrm{CO}_{2}$, resulting in an increase in $\mathrm{CO}_{2}$ absorption capacity (Thompson et al., 2014). On the contrary, excessive quantities of $\mathrm{H}_{2} \mathrm{O}$ have a negative influence on $\mathrm{CO}_{2}$ gravimetric absorption capacity of [TMGH] $[\mathrm{Im}]-\mathrm{H}_{2} \mathrm{O}$ systems due to the reducing of $[\mathrm{TMGH}][\mathrm{Im}]$ content, it is also shown that $\mathrm{CO}_{2}$ gravimetric absorption capacity becomes lower when $25 \mathrm{wt} \% \mathrm{H}_{2} \mathrm{O}$ was existed in [TMGH][Im], which was $0.149 \mathrm{~g} \mathrm{CO}_{2} / \mathrm{g}$ absorbent. The detail reason will be discussed in the section of absorption mechanism.

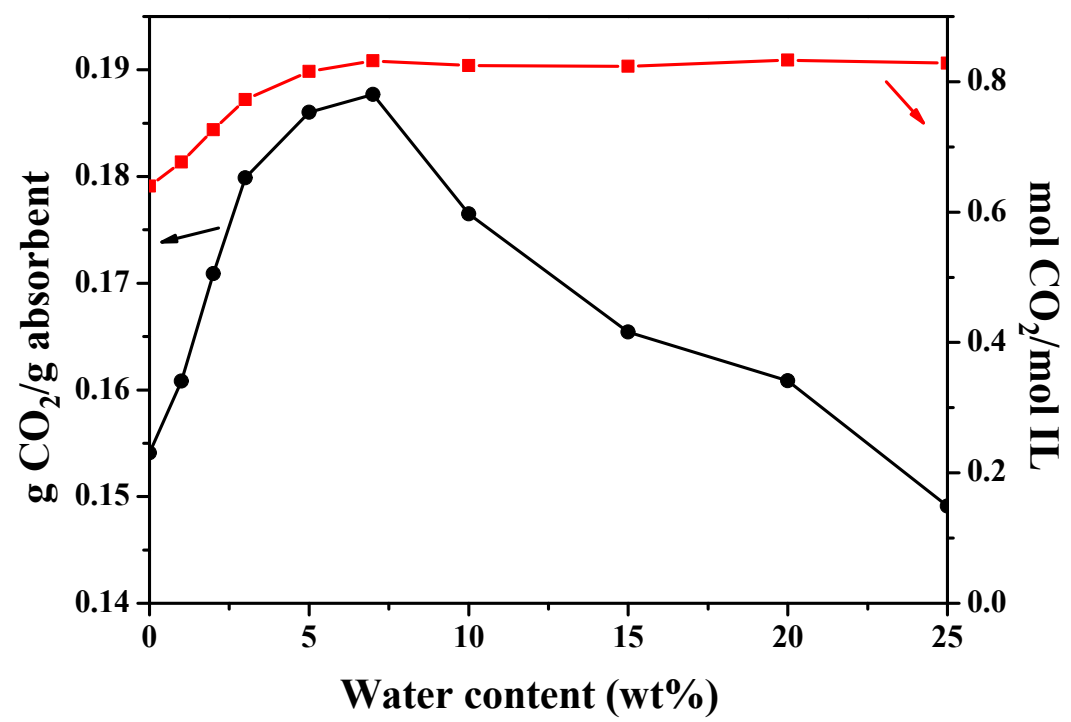

Fig. 6. $\mathrm{CO}_{2}$ absorption capacity of $[\mathrm{TMGH}][\mathrm{Im}]-\mathrm{H}_{2} \mathrm{O}$ systems at $40{ }^{\circ} \mathrm{C}$ and $1 \mathrm{bar}$. 


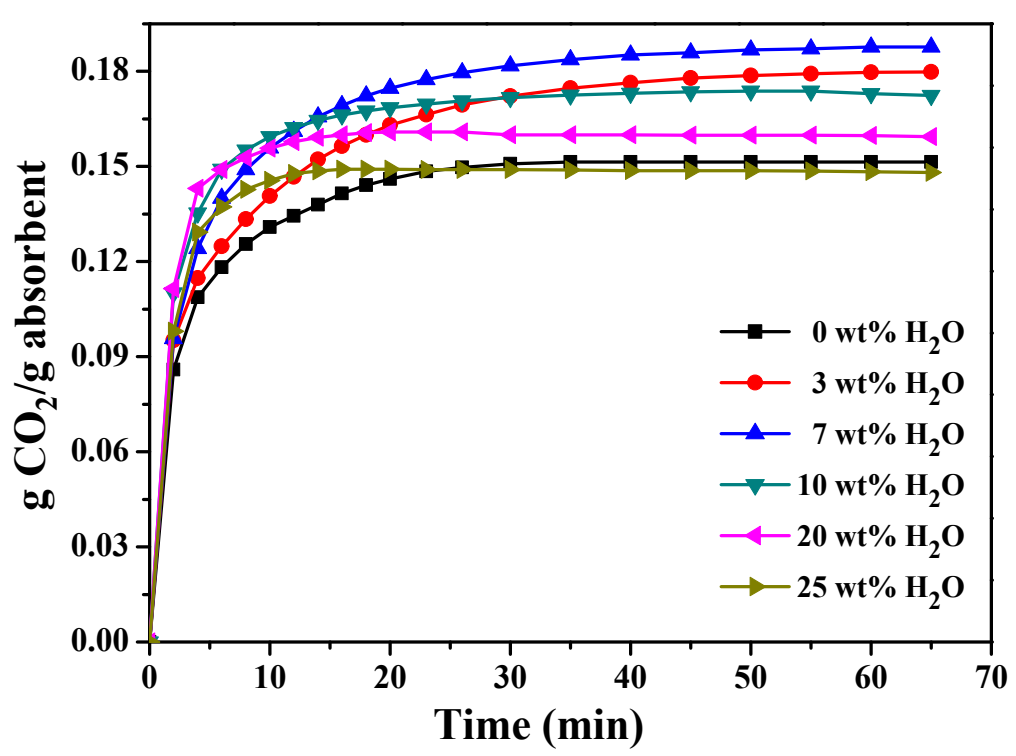

Fig. 7. Effect of water content on $\mathrm{CO}_{2}$ absorption performance of [TMGH][Im] at $40{ }^{\circ} \mathrm{C}$ and 1 bar.

\section{6. $\mathrm{CO}_{2}$ absorption mechanisms in PILs}

As aforementioned, the addition of $\mathrm{H}_{2} \mathrm{O}$ changed the $\mathrm{CO}_{2}$ absorption performance of $[\mathrm{TMGH}][\mathrm{Im}]$. In order to understand the absorption mechanism of [TMGH] [Im] in the absence and presence of $\mathrm{H}_{2} \mathrm{O}$, in-situ FTIR, ${ }^{13} \mathrm{C}$ NMR and theoretical calculations were used to analyze the interaction between ILs or IL- $\mathrm{H}_{2} \mathrm{O}$ system and $\mathrm{CO}_{2}$.

\subsubsection{In-situ FTIR and NMR analysis}

The $[\mathrm{TMGH}][\mathrm{Im}]-\mathrm{H}_{2} \mathrm{O}$ system containing $80 \mathrm{wt} \%$ [TMGH] [Im] and $20 \mathrm{wt} \% \mathrm{H}_{2} \mathrm{O}$ showed higher absorption capacity and faster absorption rate. Therefore, neat $[\mathrm{TMGH}][\mathrm{Im}]$ and $80 \mathrm{wt} \%[\mathrm{TMGH}][\mathrm{Im}]-20 \mathrm{wt} \% \mathrm{H}_{2} \mathrm{O}$ system were selected to investigate the absorption mechanism of $[\mathrm{TMGH}][\mathrm{Im}]$ in the absence and presence of $\mathrm{H}_{2} \mathrm{O}$ via in-situ FTIR and ${ }^{13} \mathrm{C}$ NMR spectra. As shown in Fig. 8, the FTIR spectra of 
the $\mathrm{CO}_{2}$-absorbed $[\mathrm{TMGH}][\mathrm{Im}]$ contained three new peaks compared to neat [TMGH][Im]. The peaks at 1700 and $1293.7 \mathrm{~cm}^{-1}$ can be attributed to the stretching vibrations of $\mathrm{C}=\mathrm{O}$ and $\mathrm{C}-\mathrm{O}$ of carbamate, respectively. The peak at $1176.3 \mathrm{~cm}^{-1}$ was appeared due to the formation of $\mathrm{C}-\mathrm{N}$. The results indicated that the carbamate was formed between the basic nitrogen of imidazole anion and $\mathrm{CO}_{2}$ (Wang et al., 2011; Zhu et al., 2017). For [TMGH][Im]- $\mathrm{H}_{2} \mathrm{O}$ system, two new characteristic peaks at 1252.7 and $1040.2 \mathrm{~cm}^{-1}$ appeared as shown in Fig. 9 verified the formation of the bicarbonate during the absorption of $\mathrm{CO}_{2}$, which means that new product was generated in the presence of $\mathrm{H}_{2} \mathrm{O}$. Furthermore, By analyzing ${ }^{13} \mathrm{C}$ NMR of [TMGH] [Im]-based solvents before and after absorption of $\mathrm{CO}_{2}$ listed in Fig. 10, a new carbon signal at 161.16 was observed in the $\mathrm{CO}_{2}$-absorbed [TMGH][Im] as compared to neat [TMGH][Im], which was attributed to carbonate carbonyl carbon, while the peak at $160.26 \mathrm{ppm}$ appeared after $\mathrm{CO}_{2}$ absorption in $[\mathrm{TMGH}][\mathrm{Im}]-\mathrm{H}_{2} \mathrm{O}$ was due to the formation of bicarbonate. (Andrews et al., 2011; Simon et al., 2017; Chen et al., 2018). The results were in agreement with relevant researches reported in literature that the basicity of anion can activate the reaction between $\mathrm{CO}_{2}$ and $\mathrm{H}_{2} \mathrm{O}$ to form conjugate acid of the basic anion and bicarbonate (Huang et al., 2019). Based on the above analysis, the possible $\mathrm{CO}_{2}$ absorption mechanism of $[\mathrm{TMGH}][\mathrm{Im}]$ in the absence and presence of $\mathrm{H}_{2} \mathrm{O}$ was proposed in Scheme 3. 


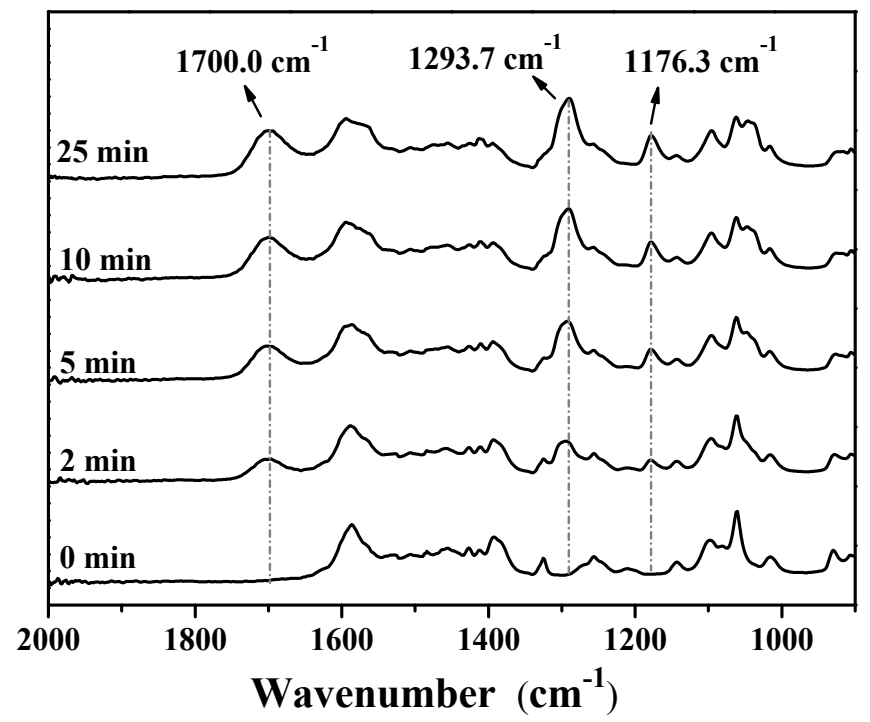

Fig. 8. FTIR spectra of [TMGH] $[\mathrm{Im}]$ before and after absorption of $\mathrm{CO}_{2}$.

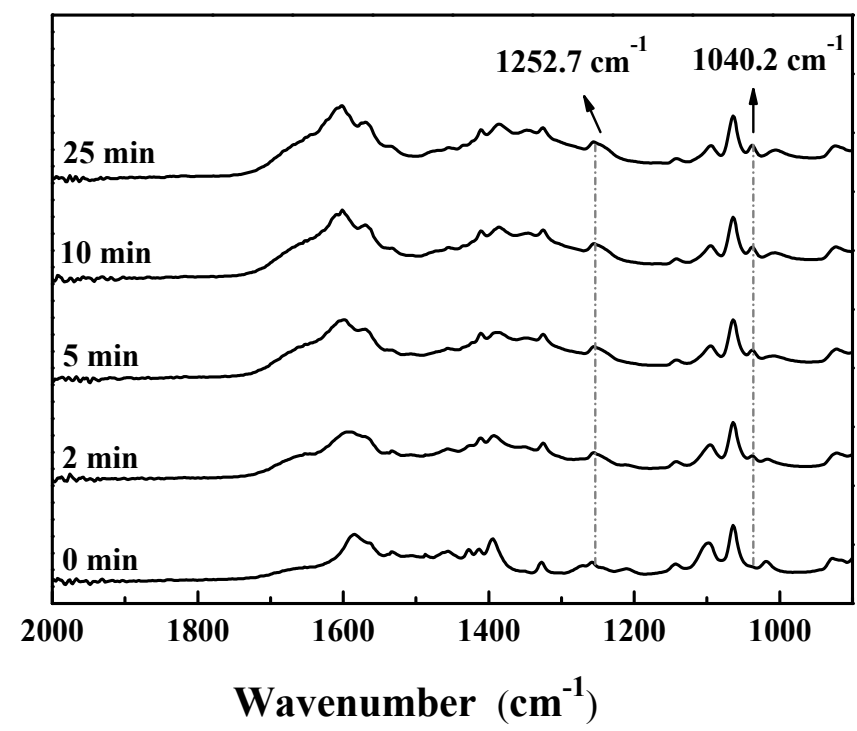

Fig. 9. FTIR spectra of $[\mathrm{TMGH}][\mathrm{Im}]-\mathrm{H}_{2} \mathrm{O}$ system before and after absorption of $\mathrm{CO}_{2}$. 


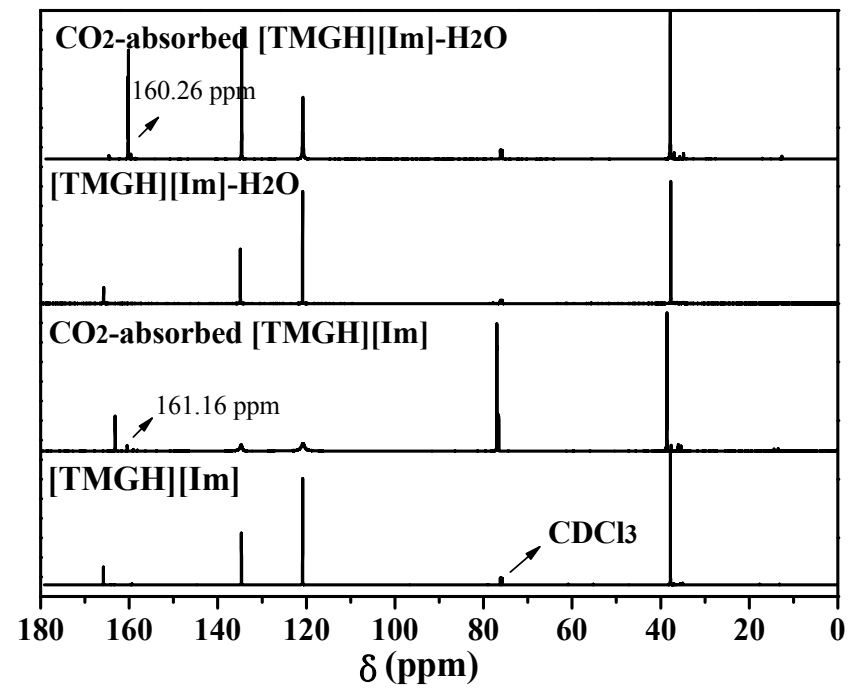

Fig. 10. ${ }^{13} \mathrm{C}$ NMR spectra of $[\mathrm{TMGH}][\mathrm{Im}]$ and $[\mathrm{TMGH}][\mathrm{Im}]-\mathrm{H}_{2} \mathrm{O}$ systems before and after absorption of $\mathrm{CO}_{2}$.

\subsubsection{Quantum chemistry calculations}

Based on the above experimental results and spectral characterizations, we proposed the possible $\mathrm{CO}_{2}$ absorption pathways of $[\mathrm{TMGH}][\mathrm{Im}]$ in the absence (pathway 1) and presence (pathway 2) of $\mathrm{H}_{2} \mathrm{O}$ in Scheme 3. During the absorption of $\mathrm{CO}_{2}$ in $[\mathrm{TMGH}][\mathrm{Im}]$, carbamate $(\mathrm{P} 1)$ is generated from the combination of nitrogen atom of $\mathrm{N} 1$ on the imidazole anion and $\mathrm{CO}_{2}$ through transition states (TS1). When $\mathrm{H}_{2} \mathrm{O}$ is existed in [TMGH][Im], the formation of N1-H4 and C2-O3 bonds generates the bicarbonate (P2) and Im via the transition states (TS2). 
Pathway 1

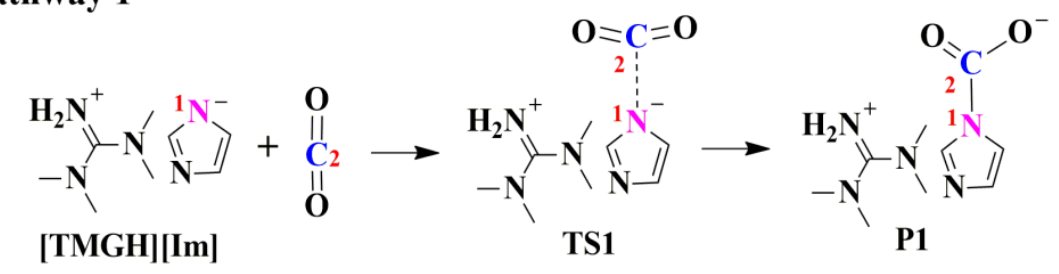

Pathway 2

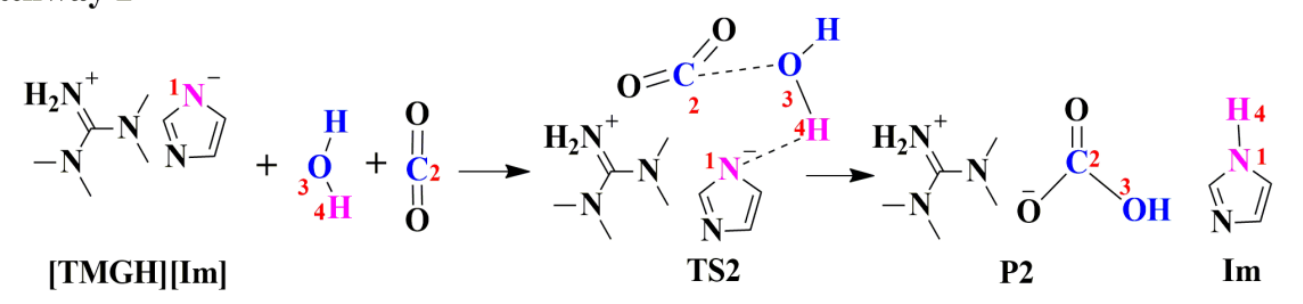

Scheme 3. $\mathrm{CO}_{2}$ absorption pathways of $[\mathrm{TMGH}][\mathrm{Im}]$ and $[\mathrm{TMGH}][\mathrm{Im}]-\mathrm{H}_{2} \mathrm{O}$ systems

The $\mathrm{CO}_{2}$ reaction potential energies for two systems are shown in Fig. 11. It can be seen that the reaction energy barriers of $\mathrm{CO}_{2}$ with $[\mathrm{TMGH}][\mathrm{Im}]$ and $[\mathrm{TMGH}][\mathrm{Im}]-$ $\mathrm{H}_{2} \mathrm{O}$ were 4.45 and $5.61 \mathrm{kcal} / \mathrm{mol}$, respectively. The low energy barriers make $\mathrm{CO}_{2}$ absorption easy to perform both in neat $[\mathrm{TMGH}][\mathrm{Im}]$ and $[\mathrm{TMGH}][\mathrm{Im}]-\mathrm{H}_{2} \mathrm{O}$ systems. The interaction energies of products $\mathrm{P} 1$ and $\mathrm{P} 2+\mathrm{Im}$ were -12.26 and $-14.86 \mathrm{kcal} / \mathrm{mol}$, respectively. These data suggested that more stable bicarbonate was generated in the presence of $\mathrm{H}_{2} \mathrm{O}$, which is in good agreement with the experimental results. 


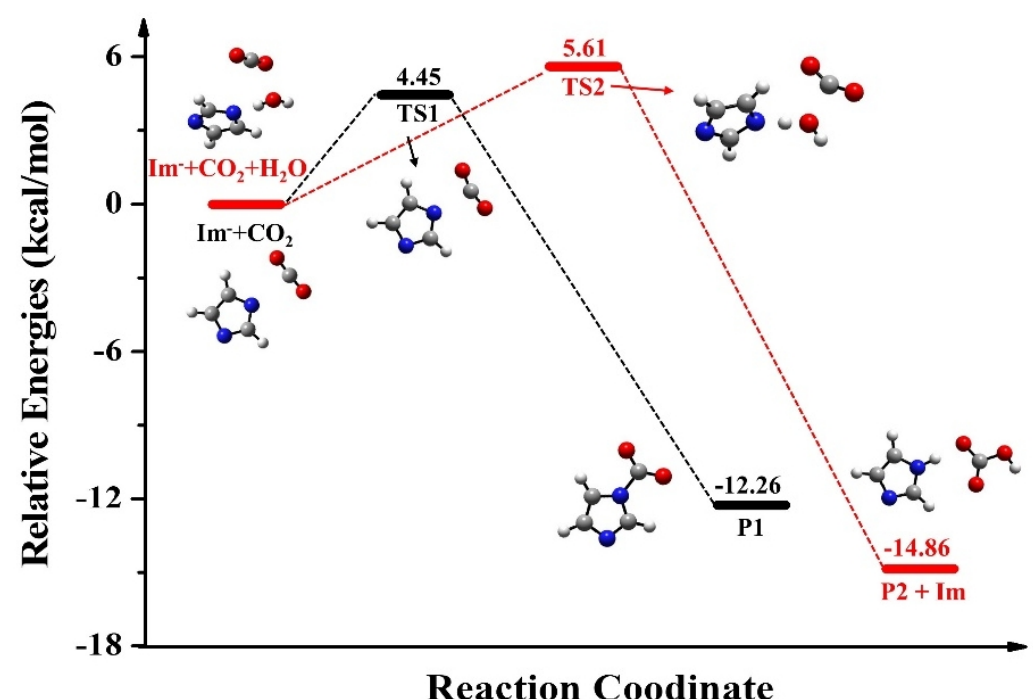

Fig. 11. Optimized structures and potential energy profiles of $\mathrm{CO}_{2}$ absorption in $[\mathrm{TMGH}][\mathrm{Im}]$ and $[\mathrm{TMGH}][\mathrm{Im}]-\mathrm{H}_{2} \mathrm{O}$ systems

\subsection{Recycle of [TMGH][Im] systems}

In order to examine the recyclability of $[\mathrm{TMGH}][\mathrm{Im}]$ systems, $\mathrm{CO}_{2}$-absorbed IL systems were regenerated and reused for $\mathrm{CO}_{2}$ absorption. As illustrated in Fig. 12, four absorption-desorption experiments by [TMGH][Im] showed that [TMGH][Im] can be repeatedly recycled without obvious loss of $\mathrm{CO}_{2}$ absorption capacity. The results indicated that $[\mathrm{TMGH}][\mathrm{Im}]$ as a novel $\mathrm{CO}_{2}$ absorbent has an excellent performance for the reutilization and effective $\mathrm{CO}_{2}$ absorption-desorption ability. 


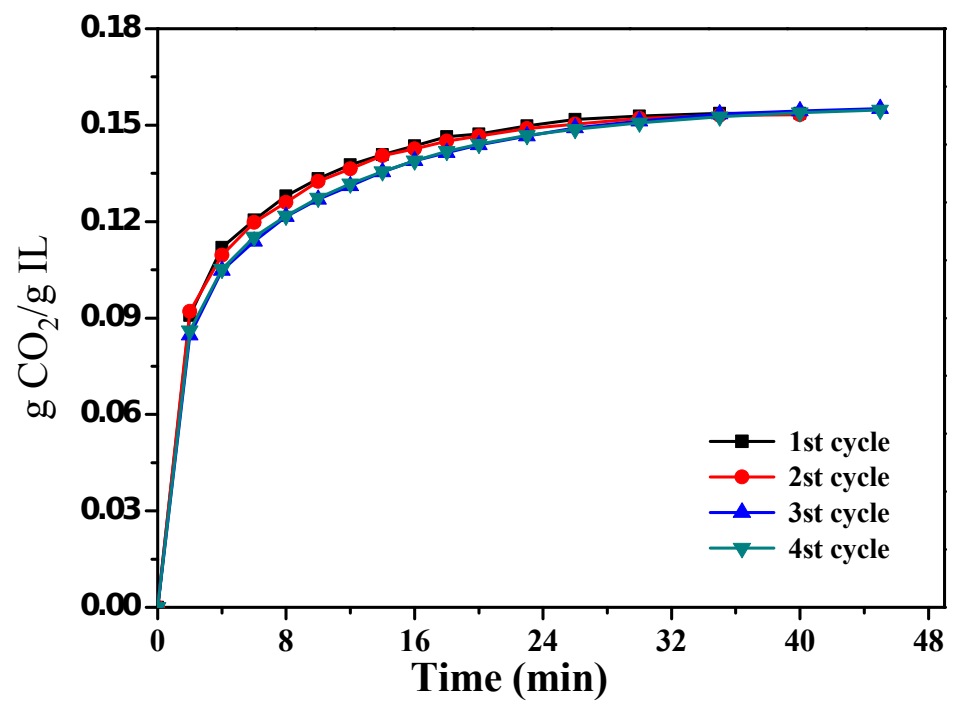

Fig. 12. Recycling of $[\mathrm{TMGH}][\mathrm{Im}]$ for $\mathrm{CO}_{2}$ absorption at $40{ }^{\circ} \mathrm{C}$ and $1 \mathrm{bar}$.

For the system of $80 \mathrm{wt} \%$ [TMGH][Im] $-20 \mathrm{wt} \% \mathrm{H}_{2} \mathrm{O}, \mathrm{CO}_{2}$ absorption capacity obviously decreased with the increasing of recycle times as demonstrated in Fig. 13. Such solvent is not suitable for industrial $\mathrm{CO}_{2}$ capture even it has high $\mathrm{CO}_{2}$ capacity in the first cycle. As seen in Fig. 11, energy barriers for the desorption of $\mathrm{CO}_{2}$ from carbamate and bicarbonate + Im systems were 16.71 and $20.47 \mathrm{kcal} / \mathrm{mol}$, separately. The higher energy barrier makes it difficult to strip $\mathrm{CO}_{2}$ from bicarbonate and Im.

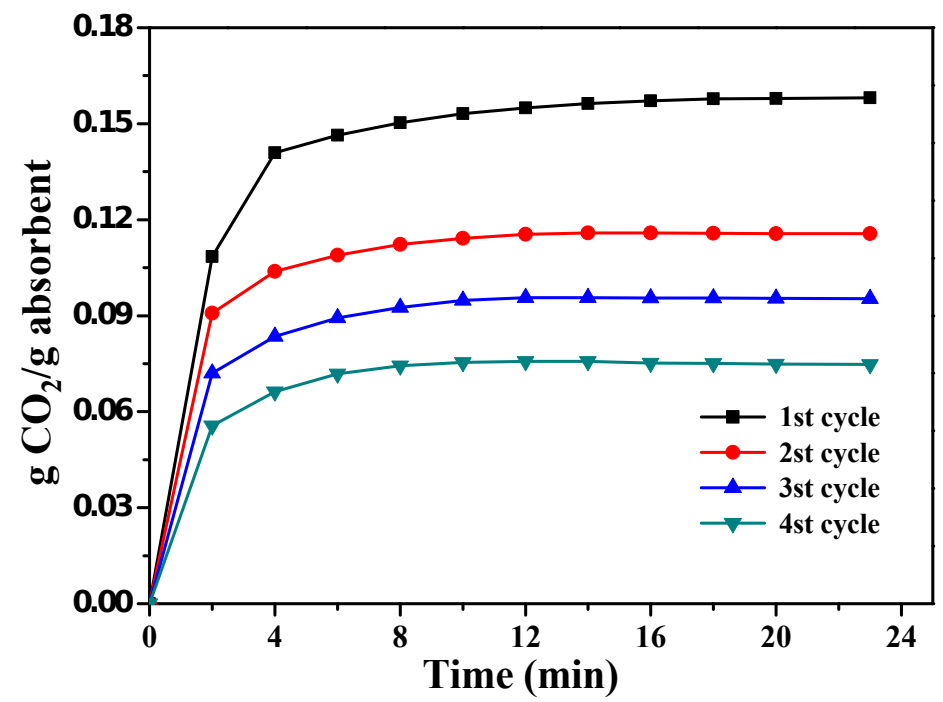

Fig. 13. Recycling of $[\mathrm{TMGH}][\mathrm{Im}]-\mathrm{H}_{2} \mathrm{O}$ system for $\mathrm{CO}_{2}$ absorption at $40{ }^{\circ} \mathrm{C}$ and 1 bar. 


\section{Conclusions}

In summary, three low viscous PILs with different basicity were designed and synthesized by one-step route for efficient absorption of $\mathrm{CO}_{2}$. The viscosity of [TMGH][Im], [TMGH][Pyrr] and [TMGH][PhO] were 6.44, 2.10 and $26.77 \mathrm{mPa} \cdot \mathrm{s}$ at $30^{\circ} \mathrm{C}$, separately, which is quite low compared with conventional ILs. The relationships between the basicity of ILs and their absorption performance of $\mathrm{CO}_{2}$ indicated that ILs with larger $\mathrm{pKa}$ of anions has higher $\mathrm{CO}_{2}$ absorption capacity. The addition of $\mathrm{H}_{2} \mathrm{O}$ changed $\mathrm{CO}_{2}$ absorption performance of [TMGH][Im], gravimetric absorption capacity of $\mathrm{CO}_{2}$ firstly increased and then decreased gradually with water content, the highest absorption capacity of $0.186 \mathrm{~g} \mathrm{CO}_{2} / \mathrm{g}$ absorbent $\left(0.83 \mathrm{~mol} \mathrm{CO}_{2} / \mathrm{mol} \mathrm{IL}\right)$ at $40{ }^{\circ} \mathrm{C}$ and 1 bar was obtained in $93 \mathrm{wt} \%[\mathrm{TMGH}][\mathrm{Im}]-7 \mathrm{wt} \% \mathrm{H}_{2} \mathrm{O}$ system. In-situ FTIR, ${ }^{13} \mathrm{C}$ NMR and theoretical calculations confirmed that carbamate can be formed reversibly during the absorption of $\mathrm{CO}_{2}$ in $[\mathrm{TMGH}][\mathrm{Im}]$, the good recyclability after four absorptiondesorption cycles indicating that $[\mathrm{TMGH}][\mathrm{Im}]$ as a potential alternative for $\mathrm{CO}_{2}$ capture has an excellent performance for the effective $\mathrm{CO}_{2}$ absorption-desorption ability. The existence of $\mathrm{H}_{2} \mathrm{O}$ result in larger energy barrier during the desorption of $\mathrm{CO}_{2}$, so it is necessary to make sure that water content in $[\mathrm{TMGH}][\mathrm{Im}]$ is quite low to ensure excellent recyclability of $[\mathrm{TMGH}][\mathrm{Im}]$ in $\mathrm{CO}_{2}$ capture application.

\section{Acknowledgment}

This work was financially supported by the National Key Research and Development Program of China (2017YFB0603301); the National Natural Science 
Foundation of China (21838010, 21425625 and 21890764); the Beijing Municipal Natural Science Foundation (2182071); and the Key Research Program of Frontier Sciences, CAS (QYZDY-SSW-JSC011).

\section{Reference}

Alcantara, M.L., de Carvalho, M.L., Alvarez, V.H., Ferreira, P.I.S., Paredes, M.L.L., Cardozo, L., Silva, A.K., Liao, L.M., Pires, C.A.M., Mattedi, S., 2018. High pressure vapor-liquid equilibria for binary carbon dioxide and protic ionic liquid based on ethanolamines plus butanoic acid. Fluid Phase Equilib. 460, 162-174.

Alcantara, M.L., Santos, J.P., Loreno, M., Ferreira, P.I.S., Paredes, M.L.L., Cardozo, L., Silva, A.K., Liao, L.M., Pires, C.A.M., Mattedi, S., 2018. Low viscosity protic ionic liquid for $\mathrm{CO}_{2} / \mathrm{CH}_{4}$ separation: Thermophysical and high-pressure phase equilibria for diethylammonium butanoate. Fluid Phase Equilib. 459, 30-43.

Andrews, N.J., Haynes, C.J.E., Light, M.E., Moore, S.J., Tong, C.C., Davis, J.T., Harrell, W.A., Jr., Gale, P.A., 2011. Structurally simple lipid bilayer transport agents for chloride and bicarbonate. Chem. Sci. 2(2), 256-260.

Bates, E.D., Mayton, R.D., Ntai, I., Davis, J.H., 2002. $\mathrm{CO}_{2}$ capture by a task-specific ionic liquid. J. Am. Chem. Soc. 124(6), 926-927.

Bernales, V.S., Marenich, A.V., Contreras, R., Cramer, C.J.,Truhlar, D.G., 2012. Quantum mechanical continuum solvation models for ionic liquids. J. Phys. Chem. B 116(30), 9122-9129.

Blanchard, L.A., Hancu, D., Beckman, E.J.,Brennecke, J.F., 1999. Green processing using ionic liquids and $\mathrm{CO}_{2}$. Nature 399(6731), 28-29. 
Bordwell, F.G., 1988. Equilibrium acidities in dimethyl-sulfoxide solution. Accounts Chem. Res. 21(12), 456-463.

Bordwell, F.G., Drucker, G.E., Fried, H.E., 1981. Acidities of carbon and nitrogen acids-the aromaticity of the cyclopentadienyl anion. J. Org. Chem. 46(3), 632-635.

Cao, L.D., Gao, J.B., Zeng, S.J., Dong, H.F., Gao, H.S., Zhang, X.P., Huang, J.H., 2017. Feasible ionic liquid-amine hybrid solvents for carbon dioxide capture. Int. J. Greenh. Gas Con. 66, 120-128.

Chen, C.-H., Shimon, D., Lee, J.J., Mentink-Vigier, F., Hung, I., Sievers, C., Jones, C. W., Hayes, S.E., 2018. The "missing" bicarbonate in $\mathrm{CO}_{2}$ chemisorption reactions on solid amine sorbents. J. Am. Chem. Soc. 140(28), 8648-8651.

Deng, L.Y., 2016. $\mathrm{CO}_{2}$ capture: challenge and opportunities. Green Energy \& Environment 1(3), 179.

Frisch, M.J., Trucks, G.W., Schlegel, H.B., Scuseria, G.E., Robb, M.A., Cheeseman, J.R., Scalmani, G, Barone, V, Mennucci, B, Petersson, G.A., Nakatsuji, H., Caricato, M., Li, X., Hratchian, H.P., Izmaylov, A.F., Bloino, J., Zheng, G., Sonnenberg, J.L., Hada, M., Ehara, M., Toyota, K., Fukuda, R., Hasegawa, J., Ishida, M., Nakajima, T., Honda, Y., Kitao, O., Nakai, H., Vreven, T., Peralta, J.E., Ogliaro, F., Bearpark, M., Heyd, J.J., Brothers, E., Kudin, K.N., Staroverov, V.N., Keith, T., Kobayashi, R., Normand, J., Raghavachari, K., Rendell, A., Burant, J.C., Iyengar, S.S., Tomasi, M.C., Rega, J.M.M., Klene, M., Knox, J.E., Cross, J.B., Bakken, C.A., Jaramillo, Gomperts, R., Stratmann, O.Y., Austin, R., Cammi, C.P., Ochterski, R.L.M., Morokuma, V.G.Z., Voth, G.A., P Salvador, J.J.D., Dapprich, S., Daniels, A.D., 
Farkas, O., Foresman, J.B., Ortiz, J.V., Cioslowski, J., Fox, D.J., 2013. Gaussian 09, revision D.01, in, Gaussian, Inc., Wallingford CT.

Gao, J.B., Cao, L.D., Dong, H.F., Zhang, X.P.,Zhang, S.J., 2015. Ionic liquids tailored amine aqueous solution for pre-combustion $\mathrm{CO}_{2}$ capture: Role of imidazoliumbased ionic liquids. Appl. Energ. 154, 771-780.

Guo, Z., Liu, P., Ma, L.W., Li, Z., 2015. Effects of Low-carbon technologies and enduse electrification on energy-related greenhouse gases mitigation in China by 2050 . Energies 8(7), 7161-7184.

Han, B., Zhou, C.G., Wu, J.P., Tempel, D.J., Cheng, H.S., 2011. Understanding $\mathrm{CO}_{2}$ capture mechanisms in aqueous monoethanolamine via first principles simulations. J. Phys. Chem. Lett. 2(6), 522-526.

Hu, H., Li, F., Xia, Q., Li, X.D., Liao, L., Fan, M.H., 2014. Research on influencing factors and mechanism of $\mathrm{CO}_{2}$ absorption by poly-amino-based ionic liquids. Int. J. Greenh. Gas Con. 31, 33-40.

Huang, Q.S., Jing, G.H., Zhou, X.B., Lv, B.H., Zhou, Z.M., 2018. A novel biphasic solvent of amino-functionalized ionic liquid for $\mathrm{CO}_{2}$ capture: High efficiency and regenerability. J. $\mathrm{CO}_{2}$ Util. 25, 22-30.

Huang, Y.J., Cui, G.K., Zhao, Y.L., Wang, H.Y., Li, Z.Y., Dai, S.,Wang, J.J., 2017. Preorganization and cooperation for highly efficient and reversible capture of lowconcentration $\mathrm{CO}_{2}$ by ionic liquids. Angew. Chem. Int. Edit. 56(43), 13293-13297. Huang, Y.J., Cui, G.K., Zhao, Y.L., Wang, H.Y., Li, Z.Y., Dai, S.,Wang, J.J., 2019. Reply to the correspondence on "Preorganization and cooperation for highly 
efficient and reversible capture of low-concentration $\mathrm{CO}_{2}$ by ionic liquids". Angew. Chem. Int. Edit. 58, 386-389.

Jessop, P.G., Mercer, S.M.,Heldebrant, D.J., 2012. $\mathrm{CO}_{2}$-triggered switchable solvents, surfactants, and other materials. Energ. Environ. Sci. 5(6), 7240-7253.

Jin, M.J., Hou, Y.C., Wu, W.Z., Ren, S.H., Tian, S.D., Xiao, L.,Lei, Z.G., 2011. Solubilities and thermodynamic properties of $\mathrm{SO}_{2}$ in Ionic Liquids. J. Phys. Chem. B 115(20), 6585-6591.

Kumar, P.S., Hogendoorn, J.A., Feron, P.H.M.,Versteeg, G.F., 2003. Equilibrium solubility of $\mathrm{CO}_{2}$ in aqueous potassium taurate solutions: Part 1. Crystallization in carbon dioxide loaded aqueous salt solutions of amino acids. Ind. Eng. Chem. Res. 42(12), 2832-2840.

Lazarevic, A., Karamarkovic, V., Lazarevic, D., Karamarkovic, R., 2017. Potentials and opportunities to reduce energy-related greenhouse gas emissions in Serbia. Energy Sources Part A-Recovery Util. Environ. Eff. 39(7), 712-719.

Lv, B.H., Xia, Y.F., Shi, Y., Liu, N., Li, W.,Li, S.J., 2016. A novel hydrophilic amino acid ionic liquid $\mathrm{C}(2) \mathrm{OHmim}$ Gly as aqueous sorbent for $\mathrm{CO}_{2}$ capture. Int. J. Greenh. Gas Con. 46, 1-6.

Meng, X.C., Wang, J.Y., Xie, P.T., Jiang, H.C., Hu, Y.Q.,Chang, T., 2018. Structure and $\mathrm{SO}_{2}$ absorption properties of Guanidinium-based dicarboxylic acid ionic liquids. Energ. Fuel 32(2), 1956-1962.

Mondal, M.K., Balsora, H.K.,Varshney, P., 2012. Progress and trends in $\mathrm{CO}_{2}$ capture/separation technologies: A review. Energy 46(1), 431-441. 
Mumford, K.A., Pas, S.J., Linseisen, T., Statham, T.M., Nicholas, N.J., Lee, A., Kezia, K., Vijayraghavan, R., MacFarlane, D.R.,Stevens, G.W., 2015. Evaluation of the protic ionic liquid, $\mathrm{N}, \mathrm{N}$-dimethyl-aminoethylammonium formate for $\mathrm{CO}_{2}$ capture. Int. J. Greenh. Gas Con. 32, 129-134.

Oncsik, T., Vijayaraghavan, R., MacFarlane, D.R., 2018. High $\mathrm{CO}_{2}$ absorption by diamino protic ionic liquids using azolide anions. Chem. Commun. 54(17), 21062109.

Ozturk, I., 2015. Measuring the impact of energy consumption and air quality indicators on climate change: evidence from the panel of UNFCC classified countries. Environ. Sci. Pollut. Res. 22(20), 15459-15468.

Palomar, J., Gonzalez-Miquel, M., Polo, A.,Rodriguez, F., 2011. Understanding the physical absorption of $\mathrm{CO}_{2}$ in ionic liquids using the COSMO-RS method. Ind. Eng. Chem. Res. 50(6), 3452-3463.

Porwal, J., Kumar, S., Kaul, S., Jain, S.L., 2016. Guanidine based task specific ionic liquids for the synthesis of biolubricant range esters under solvent-free condition. RSC Adv. 6(96), 93640-93644.

Ramdin, M., de Loos, T.W., Vlugt, T.J.H., 2012. State-of-the-art of $\mathrm{CO}_{2}$ capture with ionic liquids. Ind. Eng. Chem. Res. 51(24), 8149-8177.

Reddy, M.V., Valasani, K.R., Lim, K.T., Jeong, Y.T., 2015. Tetramethylguanidinium chlorosulfonate ionic liquid (TMG IL): an efficient reusable catalyst for the synthesis of tetrahydro-1H-benzo a -chromeno 2,3-c phenazin-1-ones under solvent-free conditions and evaluation for their in vitro bioassay activity. New J. 
Chem. 39(12), 9931-9941.

Ritchie, C.D., 1969. Proton transfer in dipolar aprotic solvents .V. solvation and geometric factors in rates of proton transfer reactions. J. Am. Chem. Soc. 91(24), $6749-6753$.

Saravanamurugan, S., Kunov-Kruse, A.J., Fehrmann, R., Riisager, A., 2014. Aminefunctionalized amino acid- based ionic liquids as efficient and high- capacity absorbents for $\mathrm{CO}_{2}$. Chemsuschem 7(3), 897-902.

Shang, D.W., Zhang, X.P., Zeng, S.J., Jiang, K., Gao, H.S., Dong, H.F., Yang, Q.Y., Zhang, S.J., 2017. Protic ionic liquid Bim $\mathrm{NTf}_{2}$ with strong hydrogen bond donating ability for highly efficient ammonia absorption. Green. Chem. 19(4), 937-945.

Simon, N.M., Zanatta, M., dos Santos, F.P., Corvo, M.C., Cabrita, E.J.,Dupont, J., 2017. Carbon dioxide capture by aqueous ionic liquid solutions. Chemsuschem 10(24), 4927-4933.

Singh, A.P., Sithambaram, D., Sanghavi, R., Gupta, P.K., Verma, R.S., Doble, M., Gardas, R.L., Senapati, S., 2017. Environmentally benign tetramethylguanidinium cation based ionic liquids. New J. Chem. 41(20), 12268-12277.

Sistla, Y.S., Khanna, A., 2011. Validation and prediction of the temperature-dependent Henry's constant for $\mathrm{CO}_{2}$-ionic liquid systems using the conductor-like screening model for realistic solvation (COSMO-RS). J. Chem. Eng. Data 56(11), 4045-4060.

Thompson, R.L., Shi, W., Albenze, E., Kusuma, V.A., Hopkinson, D., Damodaran, K., Lee, A.S., Kitchin, J.R., Luebke, D.R.,Nulwala, H., 2014. Probing the effect of electron donation on $\mathrm{CO}_{2}$ absorbing 1,2,3-triazolide ionic liquids. RSC Adv. 4(25), 
12748-12755.

Vaidya, P.D.,Kenig, E.Y., 2007. $\mathrm{CO}_{2}$-alkanolamine reaction kinetics: A review of recent studies. Chem. Eng. Technol. 30(11), 1467-1474.

Wang, C.M., Luo, X.Y., Luo, H.M., Jiang, D.E., Li, H.R.,Dai, S., 2011. Tuning the basicity of ionic liquids for equimolar $\mathrm{CO}_{2}$ capture. Angew. Chem. Int. Edit. 50(21), 4918-4922.

Wang, J., Zeng, S.J., Bai, L., Gao, H.S., Zhang, X.P., Zhang, S.J., 2014. Novel etherfunctionalized pyridinium chloride ionic liquids for efficient $\mathrm{SO}_{2}$ capture. Ind. Eng. Chem. Res. 53(43), 16832-16839.

Wu, W.Z., Han, B.X., Gao, H.X., Liu, Z.M., Jiang, T., Huang, J., 2004. Desulfurization of flue gas: $\mathrm{SO}_{2}$ absorption by an ionic liquid. Angew. Chem. Int. Edit. 43(18), $2415-2417$.

$\mathrm{Xu}$, Y.J., 2017. $\mathrm{CO}_{2}$ absorption behavior of azole-based protic ionic liquids: Influence of the alkalinity and physicochemical properties. J. $\mathrm{CO}_{2}$ Util. 19, 1-8.

Zeng, S.J., Gao, H.S., Zhang, X.C., Dong, H.F., Zhang, X.P., Zhang, S.J., 2014. Efficient and reversible capture of $\mathrm{SO}_{2}$ by pyridinium-based ionic liquids. Chem. Eng. J. 251, 248-256.

Zeng, S.J., Liu, L., Shang, D.W., Feng, J.P., Dong, H.F., Xu, Q.X., Zhang, X.P., Zhang, S.J., 2018. Efficient and reversible absorption of ammonia by cobalt ionic liquids through Lewis acid-base and cooperative hydrogen bond interactions. Green. Chem. 20(9), 2075-2083.

Zhang, J.Z., Jia, C., Dong, H.F., Wang, J.Q., Zhang, X.P., Zhang, S.J., 2013. A novel 
dual amino-functionalized cation-tethered ionic liquid for $\mathrm{CO}_{2}$ capture. Ind. Eng. Chem. Res. 52(17), 5835-5841.

Zhao, Y., Zhang, X., Zeng, S., Zhou, Q., Dong, H., Tian, X., Zhang, S., 2010. Density, viscosity, and performances of carbon dioxide capture in 16 absorbents of amine plus ionic liquid $+\mathrm{H}_{2} \mathrm{O}$, ionic liquid $+\mathrm{H}_{2} \mathrm{O}$, and amine $+\mathrm{H}_{2} \mathrm{O}$ systems. J. Chem. Eng. Data 55(9), 3513-3519.

Zhao, Y., Zhang, X., Zhen, Y., Dong, H., Zhao, G., Zeng, S., Tian, X.,Zhang, S., 2011. Novel alcamines ionic liquids based solvents: Preparation, characterization and applications in carbon dioxide capture. Int. J. Greenh. Gas Con. 5(2), 367-373.

Zhu, X., Song, M.L.,Xu, Y.J., 2017. DBU-based protic ionic liquids for $\mathrm{CO}_{2}$ capture. ACS Sustain. Chem. Eng. 5(9), 8192-8198. 


\section{Supporting Information}

\section{Protic ionic liquids with low viscosity for efficient and reversible capture of carbon dioxide}

Fangfang Li ${ }^{\mathrm{a}, \mathrm{b}}$, Yinge Bai ${ }^{\mathrm{a}}$, Shaojuan Zeng ${ }^{\mathrm{a},{ }^{* *}}$, Xiaodong Liang ${ }^{\mathrm{c}}$, Hui Wang ${ }^{\mathrm{a}}$, Feng Huo ${ }^{\mathrm{a}}$, Xiangping Zhanga,b,*

a Beijing Key Laboratory of Ionic Liquids Clean Process, CAS Key Laboratory of Green Process and Engineering, State Key Laboratory of Multiphase Complex Systems, Institute of Process Engineering, Chinese Academy of Sciences, Beijing 100190, China

b Sino-Danish College of University of Chinese Academy of Sciences, Beijing 100049, China

c Department of Chemical and Biochemical Engineering, Technical University of Denmark, DK-2800 Lyngby, Denmark

*Corresponding author. E-mail: xpzhang@ipe.ac.cn, Tel/Fex: 86-10-8254-4875

** Corresponding author. E-mail: sjzeng@ipe.ac.cn 


\section{FTIR data of all studied ionic liquids}

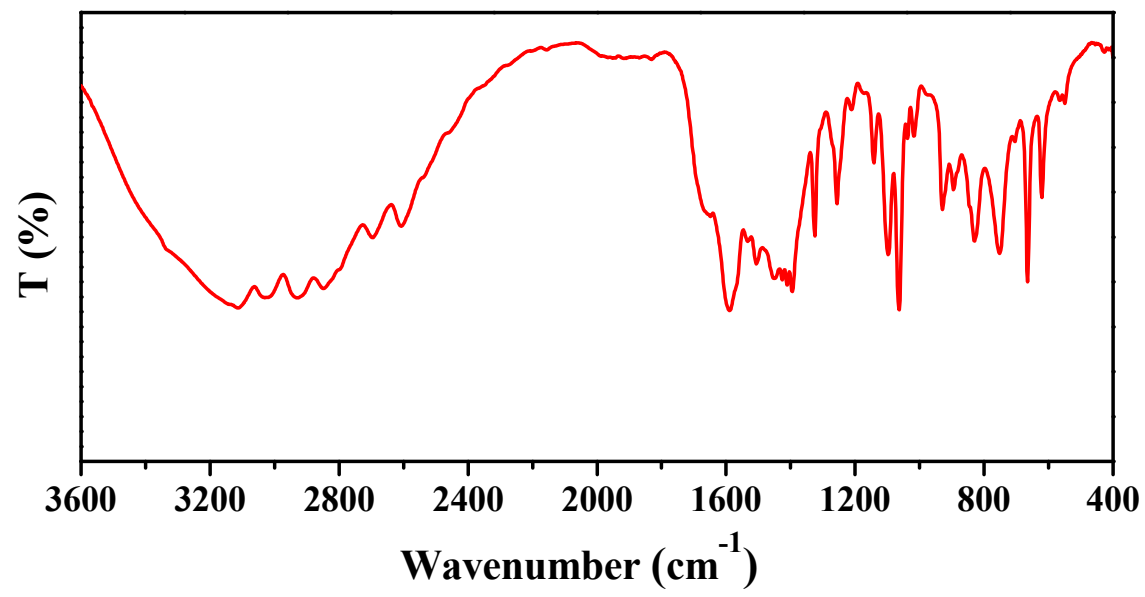

Fig. S1. FTIR spectra of [TMGH][Im]

$v=2925.51$ (the stretching vibration of $\mathrm{CH}_{3}$ ), 2696.10 (the characteristic peak of $\mathrm{N}-\mathrm{CH}_{3}$ ), 1589.07 (the stretching vibration of $\mathrm{C}=\mathrm{N}$ ), 1506.18 and 1410.72 (the stretching vibration of imidazole ring skeleton), $1063.47 \mathrm{~cm}^{-1}$ (the stretching vibration of $\mathrm{C}-\mathrm{N}$ ).

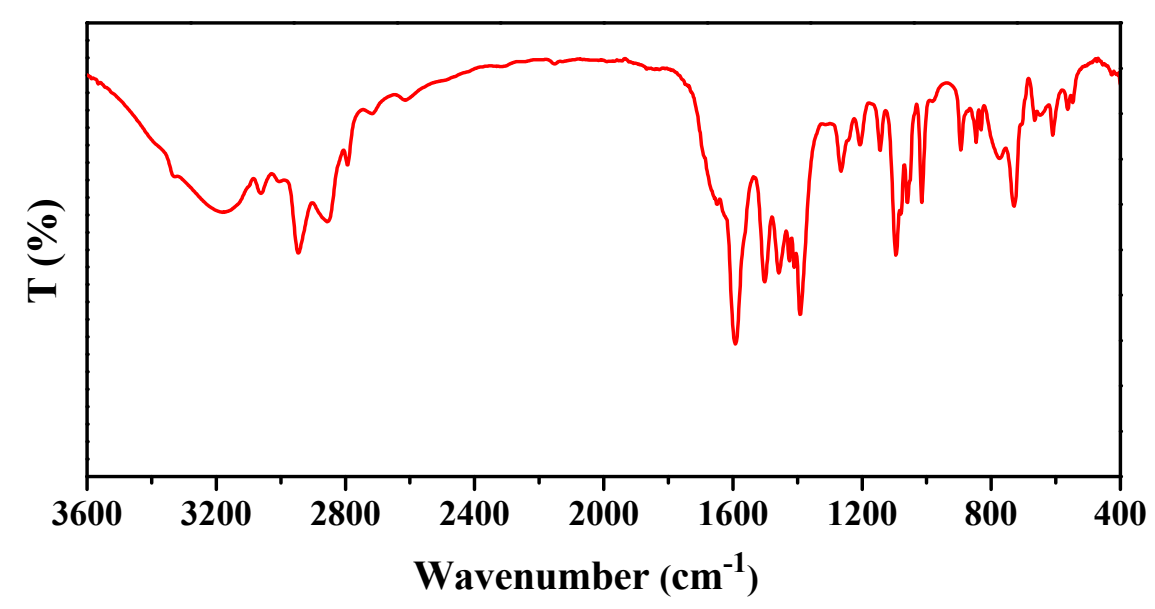

Fig. S2. FTIR spectra of [TMGH][Pyrr]

$v=2945.69$ (the stretching vibration of $\mathrm{CH}_{3}$ ), 1592.28 (the stretching vibration of $\mathrm{C}=\mathrm{N}), 1501.53$ and 1457.70 (the stretching vibration of pyrrole ring skeleton), 1095.02 $\mathrm{cm}^{-1}$ (the stretching vibration of C-N). 


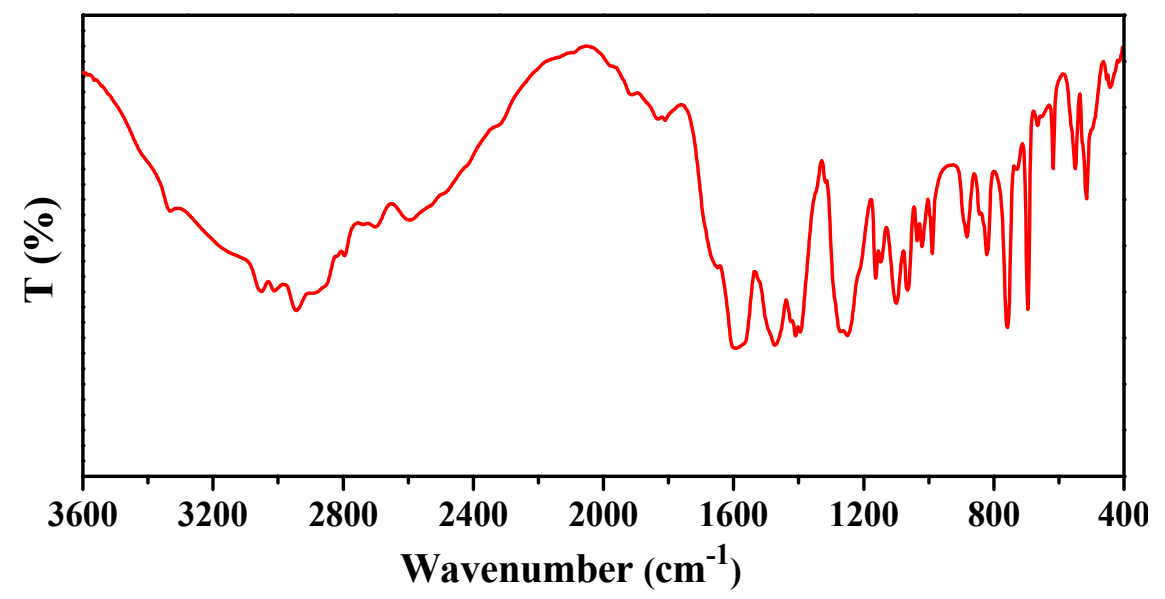

Fig. S3. FTIR spectra of [TMGH][PhO]

$v=2943.95$ (the stretching vibration of $\mathrm{CH}_{3}$ ), 2595.64 (the characteristic peak of $\mathrm{N}-\mathrm{CH}_{3}$ ), 1593.44 (the stretching vibration of $\mathrm{C}=\mathrm{N}$ ), 1472.91 and 1409.27 (the stretching vibration of imidazole ring skeleton), 1250.10 (the stretching vibration of $\mathrm{C}-\mathrm{O}$ ), $1099.71 \mathrm{~cm}^{-1}$ (the stretching vibration of $\mathrm{C}-\mathrm{N}$ ).

\section{${ }^{1} \mathrm{H}$ NMR and ${ }^{13} \mathrm{C}$ NMR data of all studied ionic liquids}

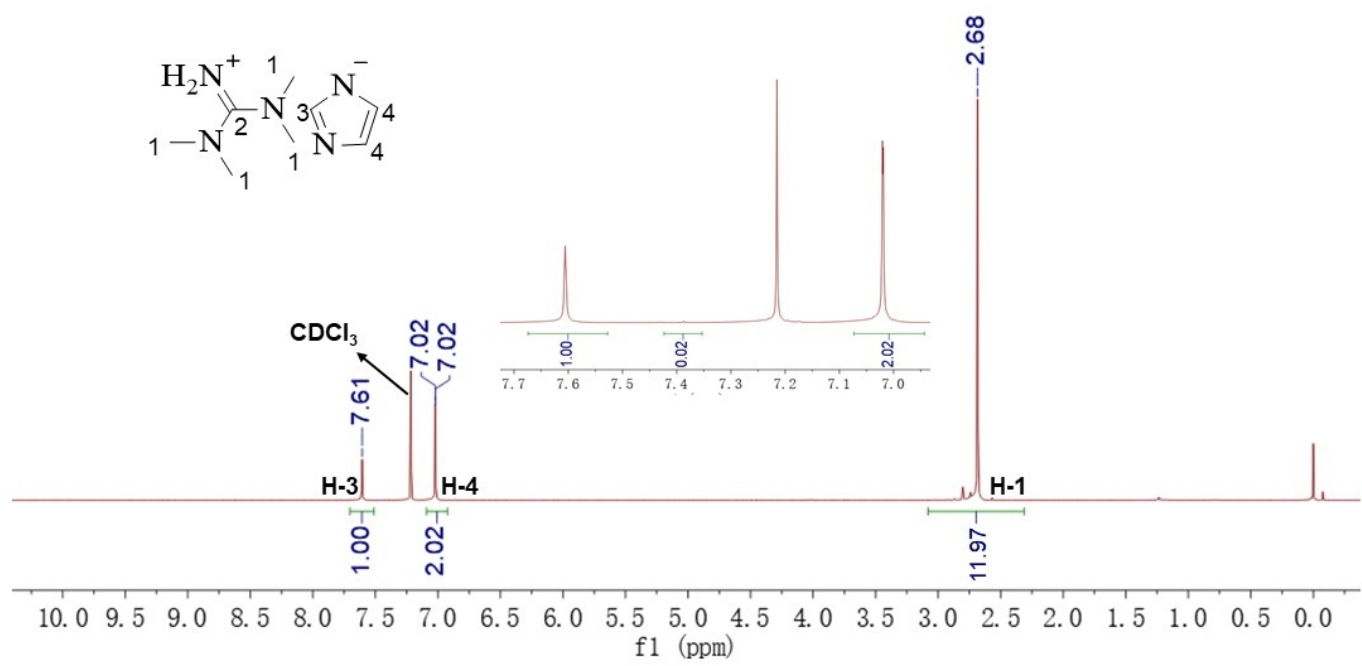

Fig. S4. ${ }^{1} \mathrm{H}$ NMR spectra of [TMGH][Im]

${ }^{1} \mathrm{H}$ NMR (600 MHz; $\mathrm{CDCl}_{3}$; TMS): 2.68 (12H, s, $\left.\mathrm{CH}_{3}\right), 7.02(2 \mathrm{H}, \mathrm{s}, \mathrm{CH}), 7.61$ $\operatorname{ppm}(1 \mathrm{H}, \mathrm{s}, \mathrm{CH})$.

The purity of $[\mathrm{TMGH}][\mathrm{Im}]$ was estimated by comparing area of the $\mathrm{CH}-3$ signal with its signal area between $\delta 7.35$ and 7.38 , the obtained purity is 0.98 . 


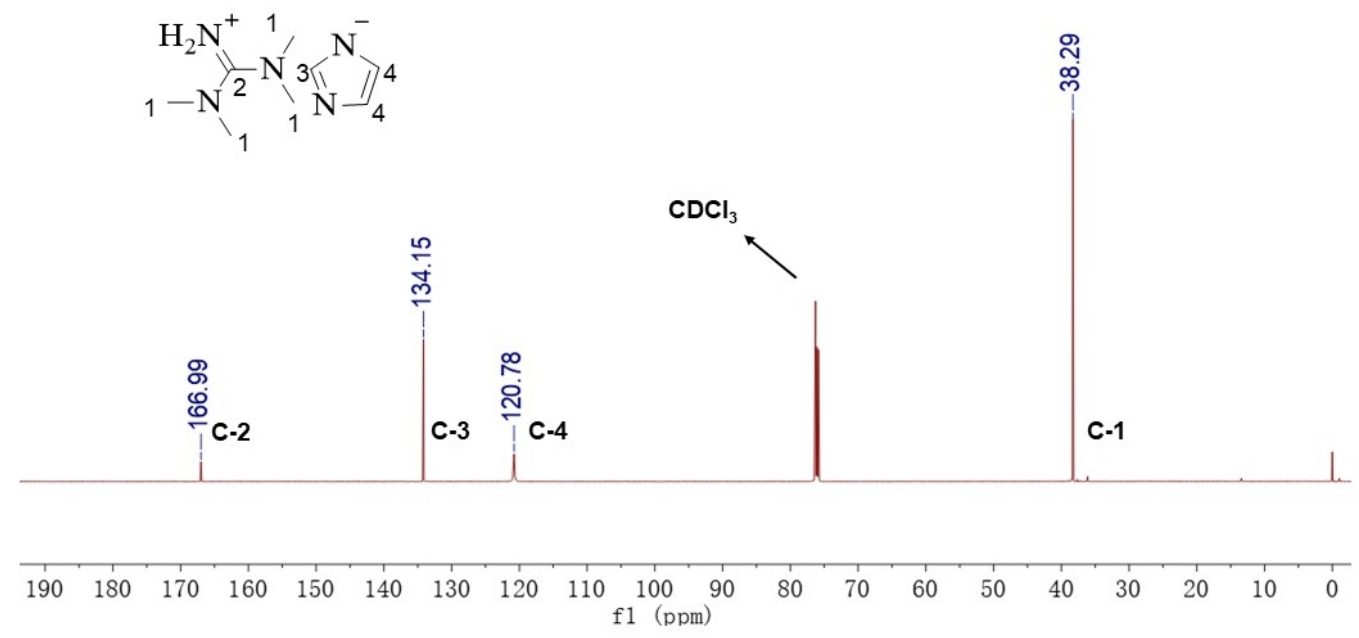

Fig. S5. ${ }^{13} \mathrm{C}$ NMR spectra of $[\mathrm{TMGH}][\mathrm{Im}]$

${ }^{13} \mathrm{C}$ NMR (600 MHz; $\mathrm{CDCl}_{3}$; TMS): 38.29, 120.78, 134.15, 166.99 ppm.

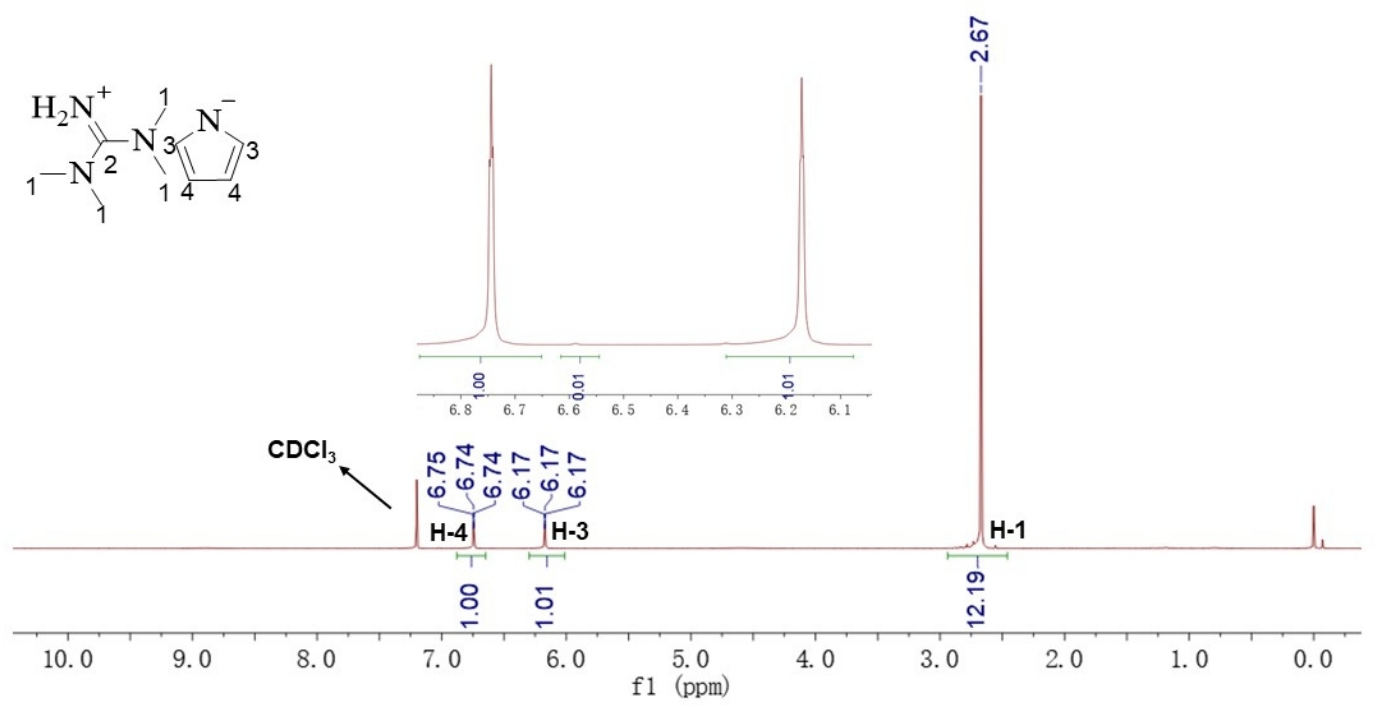

Fig. S6. ${ }^{1} \mathrm{H}$ NMR spectra of $[\mathrm{TMGH}][\mathrm{Pyrr}]$

${ }^{1} \mathrm{H}$ NMR (600 MHz; $\mathrm{CDCl}_{3}$; TMS): 2.67 (12H, s, $\left.\mathrm{CH}_{3}\right), 6.17(2 \mathrm{H}, \mathrm{d}, \mathrm{CH}), 6.74$ $\operatorname{ppm}(2 \mathrm{H}, \mathrm{d}, \mathrm{CH})$.

The purity of [TMGH][Im] was estimated by comparing area of the $\mathrm{CH}-4$ signal with its signal area between $\delta 6.55$ and 6.61 , the obtained purity is 0.99 . 


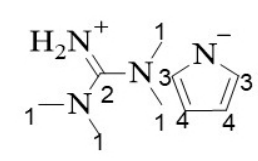
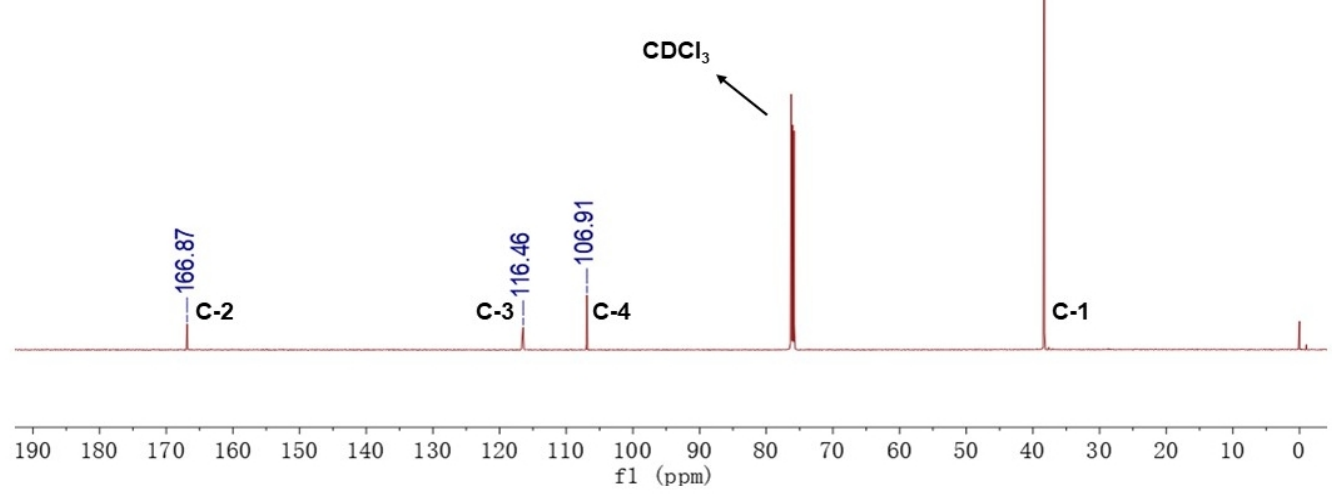

Fig. S7. ${ }^{13} \mathrm{C}$ NMR spectra of [TMGH][Pyrr]

${ }^{13} \mathrm{C}$ NMR (600 MHz; $\mathrm{CDCl}_{3}$; TMS): 38.29, 106.91, 116.46, 166.87 ppm.

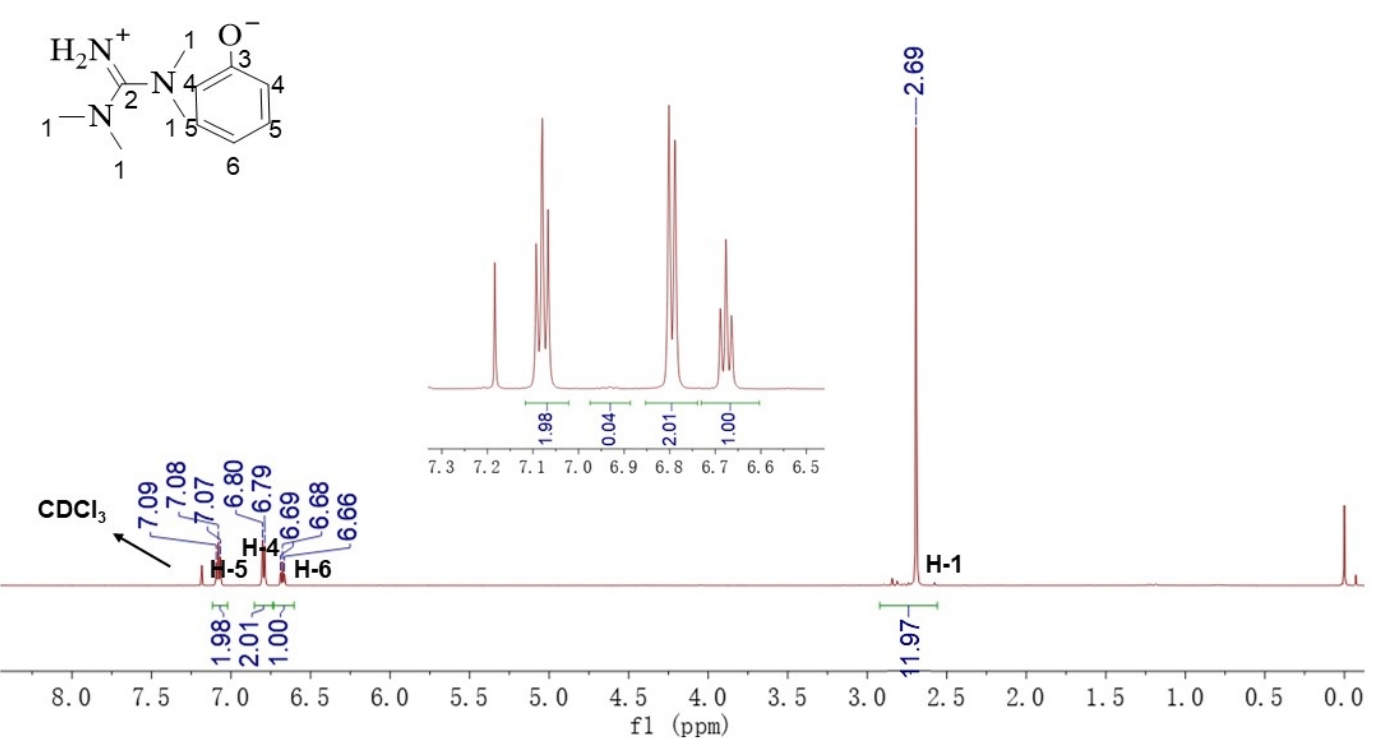

Fig. S8. ${ }^{1} \mathrm{H}$ NMR spectra of $[\mathrm{TMGH}][\mathrm{PhO}]$

${ }^{1} \mathrm{H}$ NMR (600 MHz; $\mathrm{CDCl}_{3}$; TMS): $2.69\left(12 \mathrm{H}, \mathrm{s}, \mathrm{CH}_{3}\right), 6.68(\mathrm{H}, \mathrm{t}, \mathrm{CH}), 6.79(2 \mathrm{H}$, d, $\mathrm{CH}), 7.08 \mathrm{ppm}(2 \mathrm{H}, \mathrm{t}, \mathrm{CH})$.

The purity of $[\mathrm{TMGH}][\mathrm{Im}]$ was estimated by comparing area of the $\mathrm{CH}-5$ signal with its signal area between $\delta 6.89$ and 6.96 , the obtained purity is 0.98 . 


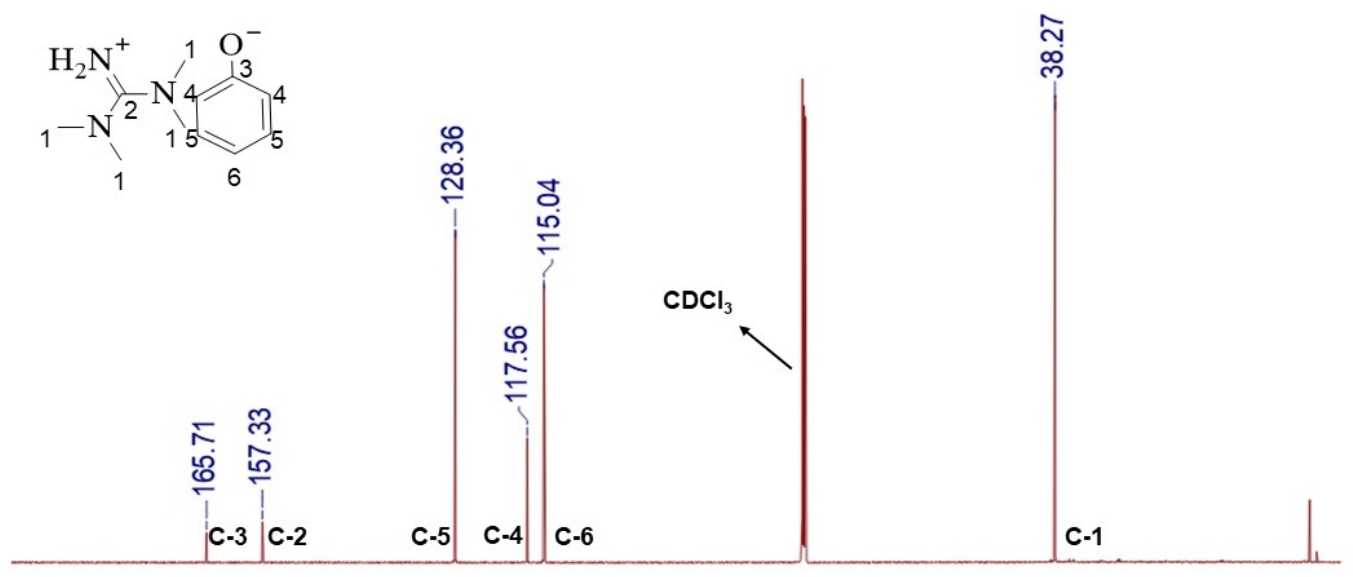

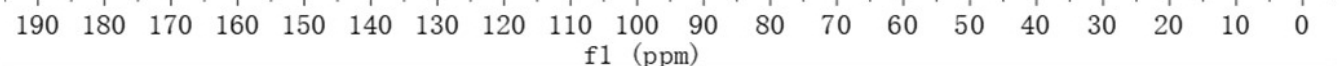

Fig. S9. ${ }^{13} \mathrm{C}$ NMR spectra of $[\mathrm{TMGH}][\mathrm{PhO}]$

${ }^{13} \mathrm{C}$ NMR (600 MHz; $\mathrm{CDCl}_{3}$; TMS): 38.27, 115.04, 117.56, 128.36, 157.33, 165.71ppm.

TGA of all studied ionic liquids

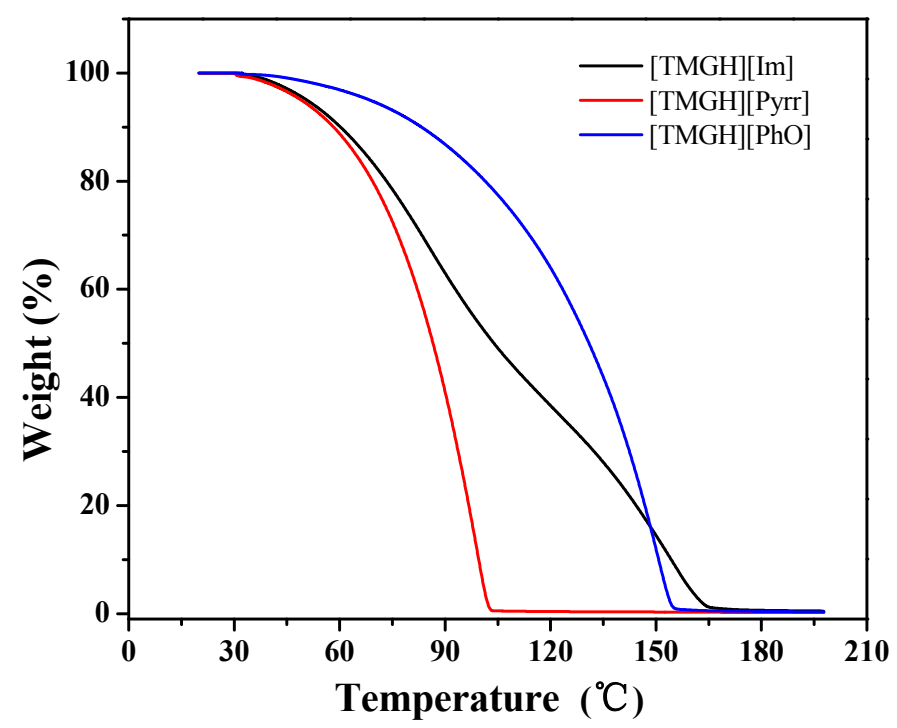

Fig. S10. TGA of [TMGH][Im]、[TMGH] $[\mathrm{Pyrr}]$ and $[\mathrm{TMGH}][\mathrm{PhO}]$ 